\title{
Documentation and Assessment on Knowledge of Ethno- Medicinal Practitioners: A Case Study on Local Meetei Healers of Manipur
}

\author{
*D. S. Ningombam ${ }^{1}$, S. P. Devi ${ }^{1}$, P. K. Singh ${ }^{1}$, A. Pinokiyo ${ }^{2} \&$ \\ Bisheswori Thongam ${ }^{3}$ \\ ${ }^{I}$ Plant Physiology Lab., Center of Advanced Study in Life Sciences, Manipur University, Manipur, India \\ ${ }^{2} P G$ Department of Botany, DM College of Science, Imphal, Manipur, India \\ ${ }^{3}$ Plant Systematic \& Conservation lab., Institute of Bioresources\& Sustainable Development, Takyelpat, \\ Manipur, India
}

\begin{abstract}
The traditional medicinal healersof the state Manipurare generally known as Maibas for male health practioner and Maibis in case of female health practioner. Since time immemorial they are involved in prescribing folk-medicine with the help of herbal-medicine or mystic incantation. An investigation on 41 local Maiba and Maibi of Meetei community of Manipur is carried out to find reliability of their knowledge, and tested if these were related significantly to age, literacy, hesitation, results of their treatment, doses and to document such know ledges based on a total of 205 locally available medicinal plant spp. belonging to 87 families used for treating 18 major diseases classes. Traditional medicinal practioners were also interviewed to gather information regarding knowledge of folk medicinal system, diagnostic system of ailments, classification of folk medicinal system, nomenclatural system and uses of medicinal plants found in Manipur as a remedy for various primary health complaints. In the present study three types folk medicinal system were recorded. The diagnostic system is bases on pulsation and symptoms. Nomenclature of medicinal plants was made in with reference to its medicinal value and traditional culture for easy identification. The Meetei forefathers put several norms for do and don'ts of eating food plants accordingly to the season and its consequences. Most of the species (72.20\%) were wild species and the part used for medicinal properties were above-ground (83.41\%) amongst which leaves (27.80\%) were mainly harvested. Concoction mode of preparation (21.46\%) is the most common way of preparation and gastrointestinal ailments (13.170\%) constitute the major ailments treated. About 55.60\% of the medicinal plants collected were taken orally taken internally for treatment of various primary health ailments. For some ailments like jaundice, snake bites, dog bites and stone cases, etc, more than 90\% of the Manipuris preferred folk medicine rather than modern medicine. Age interval 56 and above constitute $70.7 \%$ of the informants of which majority of them are excellent professionals (46.3\%) in the field of medicine of which almost $48.8 \%$ of them are illiterate. Again, age $35-45$ were persons who have good knowledge of folk medicine but lacks experience, 46 - 55 have mixed type of folk medicine knowledge where as age above 56 have a good experience and better knowledge except some who have limited knowledge of folk medicine as they are following their parents footsteps only or due to their expertise is meant for treatment of a very few diseases only.

Statistical analyses showed that there was significant correlation between the age of the informant and his knowledge of plants on folk medicine. According to our statistical analysis, spearman correlation showed significant correlation (Spearman correlation test, $r=0.5435$, at $5 \%$ level of significance) between the education level of traditional healers and the number of species reported.

Majority of herbal healers learnt their knowledge of folk medicine from mangtak (43.9\%), it is from followed by forefathers (24.4\%) and senior herbal practioners as guru (24.4\%) later other few learnt from literature. An excellent herbal practitioner could be characterized by aged (56 years and above) old experience, educated, who were accustomed with the use of wild plants, whose forefathers were herbal practitioners, who had gained high confidence of doses and cure, and with good knowledge of folk medicine and plants.
\end{abstract}

Key words: Manipuris, Maibas, Meetei, mangtak, practioner, ethno medicinal plants.

\section{Introduction}

In ancient times, medicinal plants have been used all over the world as unique sources of medicines and may constitute the most common human use of biodiversity (Bannerman 1982; Hamilton 2004; Hiremath \& Taranath, 2010). AYUSH(2003) defines traditional medicine as "The health practices approaches, knowledge and beliefs incorporating plant, animals and mineral based, medicines, spiritual therapies, method therapies manual techniques and exercises applied singularity or in combination to treat, diagnose and prevent illnesses for maintain well beings. It is argued that the traditional form of health care delivered by the traditional healers 
meets some important community-felt needs which modern or Western medicine does not meet Mankazana (1979).In India, it is estimated that approximately $70 \%$ of the population relies on traditional medicine to meet primary health care needs (Lavekar and Sharma 2005).

Since pre historic times the inhabitants of Manipur has a unique history of using medicinal plants for treatment of various primary health ailments. Manipur indigenous medicine started developing during the then king, Meidunga senbi Kiyamba (1467-1508) who use Ponheiton (Guava) as a medicine for treatment of diarrhoea. In written records, the healing practices by using herbs dates back to the then king Naophangba (428518 A.D), latter reached its climax in the reigns of king Meidunga Chingthangkhomba (1763-1798 A.D) who described well established medicine uses for plants. The meetei kings had a very sophisticated system of health, disease and treatment and appointed his personal Maibas (Herbalist) like Konnok Thengra and Meidunga Lalhamba as their Maibas respectively (Khelchandra 1969; Meitei 2004).

The herbs and wild edible medicinal plants have got great mythological significance during the prehistoric days and there are many legendary histories of many local herbal physicians (Maiba or Maibi) for their miraculous treatment using herbal medicine with mystic incarnation. The Maibas through ages recorded the experiences of indigenous medicine and compiled them in from of herbal book by them known as Puyas. The Puyas are written record handed down to posterity by the forefathers of the Meeteis written in traditional script with or without the author name maintained during king's time. The indigenous knowledge system of the herbal medicine practioners werewritten on small thin, rectangular boards of the sapwood of Aquilaria agallocha (Agar) and the ink used was made form lamp black and the pen was made from fully seasoned Bambusa tulda Roxb. . The Puyas are in the possession of various individuals and organization. Some of Puyas are Hidaklon (Folk medicine) in five volumes viz. Kanglei saglen puba puya, Shingligi maram, Laimuron, Taorinai yangbi and Thepalon. The system advocates a unique set of principles and guidelines of using traditional folk-medicine by the Manipuris. During king's times in Manipur, traditional healer has got two compartments leaded by the head Maiba known as Maiba Ahal and Maibi Ahalbi(Khelchandra 1969). However, Maiba and Maibis can be broadly divided into two types namely, (i) witch doctors-in this type of Maibas, they practice an superstitious systems, who are deeply inclined to incantation and (ii) Herbal doctors-they try to cure diseases by giving herbal medicines based on traditional systems. Traditionally, medicinal plants were conserved in-situ in Umung lai (sacred grooves) and ex-situ in their home gardens of traditional herbal practioners Maiba and Maibis(Khumbongmayum et al. 2005).

During the reign of the then king Pamheiba (1709 - 1748) embraced Hinduism in 1717 and with the instigation of the guruSantidas massive destruction of pre-hinduism records of Meetei philosophy, literature, cultural history and health and hygiene books were burned popularly known as Puya meithaba on the $17^{\text {th }}$ day, Sunday in 1654 sara (1732 A.D) in front of Kangla Uttra (Kangla Fort) (Sanajaoba 2005). Moreover another reason for the disappearance of the Puyas is the consequences of the seven years devastation war fought with the Burmese (1817 -1832 AD) where mass destruction, migration and taking away of Puyas by the captives of war to Burma who were later on absorbed to Burma.

The threatfrom the Meetei king for the custodians of the Puyas must have led to keeping those materials in secret places for a very long time. Moreover the transition of Meetei mayek script to Bengali script for a several decades makes it difficult for the younger generations to read the contents of Puyas. A catalogue of Manipur manuscript published by ManipurShahita parishad shows that the Puyas covered a number of human disciplines in which six (6) puyas were on Health and Hygiene (; Ebungohal \& Khelchandra 1967;Khelchandra 1969).

The stateis blessedwith richest repositories of medicinal and aromatic plants and moreoverwell-known for its diverse culture of human races. There is an age long intrinsic relationship between theethnicMeetei communityandmedicinal plants for the treatment of various primary health care ailments which remained endemicto this particular community of thisstate. Although, less well documented, the use of traditional medicines and consultations with traditional healers is widely acknowledged in Manipur.

The people of Manipur continued the use of folk-medicine till recent years even though modern medical science is well established. There have been many reports by different researchers in recent years on folkloric treatment with herbal medicineby the Meetei community in Manipur viz., Sinha (1987, 1996), Singh \& Singh (1995 a,b); Singh et al. (1996), Singh \& Singh 1996; Singh et al. (1997), Singh \& Singh (1997); Singh et al.(2001); Singh (2002); Elangbam (2002); Singh et al.(2003);Singh \& Singh (2003a,b), Singh \& Singh (2003); Khan (2005), Meitei et al.(2007),Devi \& Singh 2008; Srivastav et al.(2009); Singh (2009); Devi et al. 2009;Singh et al. 2010;Devi et al. (2011), Yumnam \& Triparthi (2012) andYumnmet al.(2012) reported for folkloric treatment with herbal materials that are being used to cure different diseases by the people of Manipur.

However, assessment and documentation on the reliability of knowledge of such regional practitioners is yet to be carried out for such an ethno botanically significant state. Thus, in the present study the practitioners of Meetei community in Manipur using medicinal plants were identified and assess their way of treatment, types of folk medicinal system, source of knowledge, diagnosing methods, healing methods, reliability, etc. 
It is an attempt towards the assessment of true ethno medicinal practitioners who are now decreasingand secondly to draw the attention of importance forproper documentation and conservation of these traditional knowledge of Meetei community in Manipur.

\section{Methodology}

\section{Study area}

The state Manipur is the last independent states to be incorporated into British India. Manipur formed an important link culturally and otherwise between India on one side and Southeast Asia on the other. It stretches between the $23^{\circ} 80^{\prime} \mathrm{N}-25^{\circ} 68^{\prime} \mathrm{N}$ and $93^{\circ} 03^{\prime} \mathrm{E}-94^{\circ} 78^{\prime} \mathrm{E}$ and has a geographical area of 22,327 $\mathrm{km}^{2}$ which constitutes $0.7 \%$ only to the total land surface of India (Vedaja 1998). The rich diversity of plants originates from the variations in the climatic and edaphic factors, location of the state on the confluence of Himalayas and Indo-Burma region. The region lying in the Indo-Burma Biodiversity Mega Hotspots ranks in the $8^{\text {th }}$ amongst the $34^{\text {th }}$ biodiversity hotspots of the world (Meyers et al. 2000). This holds immense potential for production and marketing of value added bio-resources in particular, spices, medicinal and aromatic plants.

\section{Study Community}

The documented history of Manipur begins with the reign of Meetei or Meitei King of Ningthouja clan Nongda Lairen Pakhangba (dragon king/god) (r. 33-154 AD), who unified the seven clans viz. Ninthouja, Angom, Khuman, Luwang, Khaba-nagba, Moirang and Sarang-Leishangthem of Meetei society (Ebungohal \& Khelchandra, 1967). Comparative ethnographic studies that it is fairly certain that the origin of Meeteis might have belonged to the Tai race of the Indo Chinese group of Mongoloids. Generally known as manipuris and are genetically mongoloid in origin and speak a Tibeto Burman language follow Shanamahism the worship of Shanamahi, the creator aspect of Shida Mapu, the trinity God of the Meeteis one of the oldest sects of Southeast Asia. It is believed to be originated form Manipur, India (Sanajoba 2005; Laishram 2009).Meeteis has well established skills, beliefs and practices relating to promotion of positive health and avoidances of sickness even before the hospitals oriented system of medicine. The economy of the people of Manipur state is basically agrarian. About $70 \%$ of the people are engaged in agriculture for their livelihood(Vedaja, 1998).

\section{Study methods \\ Survey and collection and identification of plants}

Several collection come survey tours were undertaken in the 9 districts of Manipur during the flowering seasons during the successive years April 2008 to May 2013. Plants were identified for their medicinal uses following Sinha 1996 ; Singh 2002; Singh et al., 2003; Singh, 2009. Information on the use of plants and products was collected from well known traditional healers, senior headman through personal contact and also through actual experiences. The authenticity of the uses was repeatedly verified by contacting various individuals. In case of contradictory information, efforts were made to get the correct uses. The plants were identified by following works of Clarke, 1884; Hooker (1872-97);Kanjilal et al. (1934-1940); Deb (1961 a, b); Singh \& Arora, 1978; Sinha, 1987 a, b, 1996; Singh, et al., 1988 etc. The herbarium sheets are prepared following Jain and Rao 1977 and deposited for inclusion in the herbaria of Department of Life sciences, Manipur University, India. Author name of plants follows Brummit \& Powell 1992, plant names index. All the species were thus updated following above literature in their scientific names.

Collection of data from Traditional healers or Local Physicians

For this study the Maibas or Maibis who can be defined as indigenous folk healers who are acknowledged experts in diagnosing and treatment folk illness practices by using plants and other ingredientswere selected as informants. The study was carried out for qualitative participatory documentation of the traditional healers of Meeteicommunity in Manipur. Forty one (41) such practitioners staying in different villages were selected. All the plants collected were taken to these practitioners in the form of fresh plants, herbarium specimens, photographs or local names, etc. for them to get it understand. Close ended schedule type questioner is prepared and semi structured interviews of these practitioners were taken visiting their home for each professional traditional healer who medicated the local peoples by using ethno medicinal plants or folk medicine system. Moreover, the first author got the opportunities to interact with traditional healers every second saturday as there is an association called Apunba Maiba Maibi Pharup of Manipur where maximum numbers of more than 70 active members from different communities and districts were present.Ethnomedicinal uses of the plants were collected by visiting the houses of the informants, i. e. local herbal practitioners. The method of collection of such information follows Martin 1995, Haile et al. 2007 and Isil et al. 2004 with some modifications. Some of the criteria included in the questioner for statistical analysis are age of the informant, gender, education, employment, status,folk medicinal system, diagnostic system of ailment, classification of folk medicinal system, nomenclature of medicinal plants, preferability/hesitation to treatment, outcome, effectiveness, self confidence, doses, source of knowledge, mode of preparation, transfer of knowledge, dosages 
was questioned in manipuri language which is common to all the different communities. Diseases are also categorized under 18 major groups 1). Gastrointestinal ailments (anthelmintic, colic pain, constipation, diarrhoea, dysentery, digestive complaints, gastric problems, Gastro-enteritis, indigestion \& stomach troubles, stomach ulcer, piles, to expel intestinal worms of children), 2). Respiratory system disorder (asthma, bronchitis $\&$ inflammatory diseases of the chest, cough, hiccough, irritation and inflammation of throat, sinusitis, respiratory \& breathing problems, sore mouth \& tongue disorder, tonsillitis \& throat trouble, 3). Inflammatory problems (Relieve pains \& swellings, back pain, muscular pain, inflammation due to washing and cleaning of clothes and utensils, swollen joints, reduces pain and pains caused by pointed objects, 4). Urinary ailments (urinary problems, infection and stone case), 5).Cardiovascular (hypertension, cure obesity) 6). Dermatalogical problems (boils, leprosy, pimples, cracked skins, relieves body rashes, ringworm, warts, scbies, skin diseases, hair scalp \& infection originating in a hair, small pox of children), 7). Gynaecological problems (compaints during pregnancy, easy delivery of child by pregnant women, menstrual complaints, to help conceive to occur, lecorrhoea, gonorrhoea, to prevent miscarriage, white discharge), 8).First aids (antiseptic, bruises, wounds, burns, coagulation of blood, cuts and injuries), 9. Dental problems (bleeding gums, toothache, gum bleeding), 10. Nervous disorderness (paralysis, headache, dizziness); 11. Endocrinology problem (controlling diabetes, swollen glands, dropsy, glandular swelling of neck). 12). Ear and eye problems (ear ache, catarrh, eye inflammation),13). Bone fracture (enhanced healing of bone fracture, bone setting), 14).Tonic (liver tonic, jaundice, heart disease, kidney tonic), 15). Carminative (for rejuvenating women after giving birth, health improver for adults, for nursing mother and old person), 16). Fever ( febrifuge, antipyretic); 17). Bites (dog, snake, insect bites), 18). Misscellaneous (hair care, aphrodiasiac, promoting lactation, malnutrition, enhancing vocalism by singers, mouth fresher).

Data on human ailments treated, local name, parts used, growth form, degree of management (wild/cultivated), methods of preparation, route of administration and application, existing threats to medicinal plants species and indigenous knowledge transfer were recorded. The collected medicinal plants species were made voucher specimens and the collection numbers were recorded. The collected specimens are dried, identified and deposited at Manipur University, herbarium Canchipur, Imphal, Manipur, India.

\section{Data analysis}

Chi square $\left(\mathrm{x}^{2}\right)$ test and Spearman rank correlation test were run in SPSS 12.0.1 to analyze ethno botanical data. Chi square test was used to determine whether there is any significant variation between the hesitation to medicate people with herbal medicine with the outcome of the treatment and also with the consumption of medicinal plants for every type of disease whereas Spearman rank correlation rank regression test was used to determine the correlation of knowledge of folk medicine with the age of the informant, education level, exact composition and dosages of ailments and transfer of knowledge. Analysis of types of plants, parts used major types of treatment and mode of preparation.

\section{Results and discussion}

Ethnobotanical data were collected from 41 randomly selected traditional healers using semi structured interviews and the folk medicine where common people used for self medications were also recorded. The traditional healers involved in the study were 37 were males and 4 were females ranged from 35 to 84 . Most of the healers are illiterate $(53.85 \%)$, able to read and write $(30.77 \%)$ while few $(15.38 \%)$ attended up to 10 standard and above.

\section{Types of traditional medicine practitioner}

In the present study it is recorded that there are two types of health care practitioners who supply or provide advice on herbal medicine in Manipur.The first type of health practioners are those who provide complementary and alternative medicine. They adopted traditional medicine from outside Meetei traditional culture i.eIndian system of Ayurvedic (Homeopathy and Ayurvedic). They are not considered as indigenous traditional and are known as Kabiraj or Ayurvedic doctor and the second type of traditional healers are generally known as Maibas or Maibis as male practitioner and later for female practitioner. They are unlicensed person who are involved in prescribing folk-medicine practices using indigenous traditional practices herbal remedies or person who has inherited the gift of healing or mystic incantation (magical formula or spiritually allegorical).

\section{Indigenous healing methods of Manipuris}

In the present study it was recorded that traditional healer's for the treatment of patients is based on three types of folk medicinal system namely:

(i) Napi-singbina Laiyengba(Herbal therapy) treatment with the use of herbal or medicinal plants. The health healers try to cure the diseases by giving folk medicines made form herbs, vegetables, spices etc. and other 
ingredients for preparation of different formulations for mono-herbal or poly-herbal is done. Formulations are either taken internally in form of decoction, concoction and simply boiled and taken with or without spell. Formulations of some treatment ailments are very common that the villagers themselves as homeprepared remedies.

ii) Hakchang noiduna Laiyengba (Body message system/ Reflexology system), in this type fruits, seed oil, crushed part of plants are used along with massaging is done. This mixture is applied to all body organs and massage is done by giving certain nourish effect to the skin and other body systems. The Maibas will massage firstly on the navel part with or without spell believing that navel is the centre where the souls of human being lies. After that the Maiba will keep on changing the massaging proportions one by one navel- belly- abdomenother part of the body which is found to be problematic. It is helpful in digestion, stomach problems, irregularity in menstruation, delivery problems, joints, muscle pains and for effective vibrating and re-healing activity of the human nervous system.

(iii) Lai Thajaba Laiyeng magico-religious or Psychotherapist system of folk medicine. It is the use of unseen powers to cure diseases. This practice is followed by the psychotherapist that are deeply inclined to the cure of ailments simply by incantation, oracles, performing ritual ceremonies, personal service of prayer, offering devils' gift, food vegetables, flowers, etc. In the present study this folk medicinal system is not included.

\section{Diagnosticsystem followed by the informants}

The diagnostic system followed by the ethno medicinal healers is based onMihun Kanglon yengduna Laiyengba (pulsation for diagnosing diseases) and symptoms of the particular ailment and besides this Maibas also meditate with some incantations.The right hand of male and the left hand of the female folk are usually checked pulsation. The three fingers-index, middle and ring fingers are also used by the Maiba or Maibifor the pulse examination so as to enable to examine in deeper category.

\section{Steps required of treatment of an ailment}

The efficacies of medicine depend on correct harvesting, preparation and application of medicines. The traditional health healers for the treatment of a particular disease orillnessfollow the three steps:

i). Selection of medicine: After diagnosing symptoms and pulsation,Maibas select the required plants, plant parts, seed, bark, honey, mud, animal's parts etc depending upon the type of ailments.ii). Collection of medicine:Collection is done by the Healer or patients itself depending upon the type of ailment. For collect the plant and other materials it requires some certain rules and taboos. For example; plantsparts which are directed towards east, pluck without breathing, collect on Saturday and to collect at particular timing i.emid night etc.iii). Preparation of medicine: Preparation of medicine is done at particular time depending upon the type of ailments with or without spells on it.Formulation of herbal medicine is freshly prepared Single drug remedy or monoherbaland poly herbal type. Mode of preparation isin form of decoction, concoction, as food with added ingredients, boiled and taken for internal application and porridge, crushed extract, poultice, etc. for external application.

\section{Indigenous nomenclature system of folk medicinal plants}

The folk-medicinal plants can be easily identified from the rest of the other plants according to their local names. The Meetei fore-fathers particularly those who have the knowledge of folk-medicine named in such as way that even the younger generations who has got a little knowledge of medicinal plant and identify that the very plants is having a medicinal value. The three types of classification of medicinal plants are discussed below:

A) Nomenclature of medicinal plant- The folk medicinal plants are named with the inclusion of a suffix or a prefix, so as to enable to ranked as a traditional folk medicine as follows: (i) $\operatorname{Lai}($ ii) $\operatorname{Yai}$ (iii) $\operatorname{Yen}$ (iv) $\operatorname{Hidak}$ (v)

Jam (Cham)(vi) Ningthou(vii) Kok (viii) Ren viii) Laangthrei xi) Hee and x) Utong.

Lai- Laiutong (Equisetum arvense); Yai- Takhao yai khu (Curcuma aromatic): Yen- Kongun-yen ( Cissus adanata); Hidak- Nungsi-Hidak(Mentha spicata ); Jam (Cham) - Champra (Citrus aromaticum); Ningthou- Ningthou khongli ( Tinospora cordifolia); Kok - Kokan (Alangium chinense); Ren- Tai-ren (Toona cialiata); Laangthrei- Langthrei (Eupatorium birmanicum); Hee- Mana hee- (Terminalia citrina); UtongUtong-lei ( Thevetia peruviana).

In Meeteilon language medicine is term as hidak. The word hidak is added to the name of the plant as suffix or prefix at the time of naming of the plant which has got medicinal value. For example Nungsi hidak (Mentha spicata L.) is a very important medicinal plant which is plant for treatment of gastroenteritis in Manipur and moreover it correlates those modern scientific reports. From this concept it can be concluded that Meetei community is very advanced for the classification of medicinal plants according to the literary meaning of a particular medicinal value. 
[2] Weekly Medicine -nomenclature of medicinal plants is also done based onaccording to the names of even days of a week. The Meeteiancestor's belief that some medicinal plants have their maximum curative power onaparticular day in a week. If there is some sort of serious stage of a patient for treatment of a disease, the maibal maibi prescribe a medicine which is collect and prepared on that particular day of theweek. Some of plants listed in Annexture: 1 is as set as example:

Nongmaijing (Sunday):Local name- Nongmangkha, Scientific name-(Phlogacanthus thyrsiflomis); Ningthoukaba (Monday): Ningthou-khongli (Tinospora cordifolia);Leibakpokpa (Tuesday): Leibakgnou (Artemisia nilagirica);Yumjakeisha (Wednesday): Yerum-keirum (Stellaria media);Shagolsen (Thursday): Sha-mei (Buddleja asiatica);Eerai(Friday): Ensil (Oxalis corniculata);Thangja (Saturday): Thang-hidak (Litsea sebifera).

[3] Directional Medicine -nomenclature of folk-medicinal plants were also done based oncollection systems of the plants with respect to the direction. Like in the above system nomenclature is done by adding either prefix or suffixes the eight directions to the plants name. For instance: The medicinal plants are name after the names of the eight directions as follows:

Mang/Nongpok(East): The word i.e. Mang or Nongpok are added as suffix or prefix to the name of the medicinal plant viz., Mang-Heimang (Rhus succedanea);Kha/Makha(South): Kharom-leisom, (Holmskioldia arboretum);Awang/Wang(North): Wang-dem -khoibi, (Commelina benghalensis); Meiram(South-East): Meipokpi (Opunita dillenii); Moirang Laiji(South-West): Moirang Khanum (Celerodendrum serratum); Koubru(North-West): Kou-rao- angouba (Erythrina variegata); Nongchup/Maning (West):Hei-ning, (Spondias pinnata); Chingkhei ( North-east): Ching ensile (Antidesma acidum).

The nomenclature of Meetei folk-medicinal plant according to indigenous methods of using prefixes and suffixes of vernacular way, weekly days, direction has got a significant value shows the immense expertise in the field of folk medicinal knowledge. Even though, it has got its inclination towards the superstition and incantation systems it is quite systematic and extremely helpful for the younger generation in Meetei indigenous knowledge system of medicine. The above mentioned medicinal plants are in the list of plants [Annexture: 1.]

The Meetei forefathers put several norms for do and don'ts of eating food plants accordingly to the season and consequences. The table in [Annexture: 2]shows the months (English \& Vernacular) and food (Local name \& scientific name) not to be taken andif taken its consequences in form of ailments.

A total of 205 plants belonging to cultivated (33), climbers (28), trees (46), shrubs (32) and herbs (66) arranged alphabetically under 87 families was found to be medicinally used (Table 1). The most commonly medicinally utilized families of plants were Asteraceae (17 spp.), Zingiberaceae (12 spp.), Verbenaceae ( 9 spp.), Curcubitaceae (9 spp.) as medicinally useful. Most of the species $(77.56 \%)$ were wild species and the parts used for medicinal properties were above-ground $(88.61 \%)$ amongst which leaves $(26.86 \%)$ were mainly harvested. In all the growth type i.e climbers, trees, shrubs and herbs the most used parts were leaves and in cultivated growth forms, it was fruit. Resin, tender pod, fronds, gum and pseudostem of single species each respectively were utilized. In case of small herbs, according to our informants generally the whole plant were collected entirely and taken whereas in case of large trees the twigs or stems were generally collected. An analysis on the collected plant species is provided in Table 3 .

\section{[ Insert figure:1] \\ [ Insert figure: 2]}

According to our statistical analysis, spearman correlation shows significant correlation (Spearman correlation coefficient, $r=0.5435,5 \%$ level of significance) between the education level of traditional healers and the number of species reported. There was no significant relationship (Spearman correlation coefficient, $r=$ 0.3146.) correlation was observed between the age of the informant and his knowledge of plants on folk medicine. Amongst the 41 informants $90.2 \%$ were males and only $9.8 \%$ were females. The existence of female professional herbal practitioners in recent years follows the footsteps of their expired husbands or fathers which were previously working as herbal practitioners or so called hereditary healers. Age interval 56 and above constitute $70.7 \%$ of the informants which majority of them are excellent professionals $(46.3 \%)$ in the field of medicine of which almost $48.8 \%$ of them are illiterate. Again, age $35-45$ were persons who have good knowledge of folk medicine but lacks experience, 46- 55 have mixed type of folk medicine knowledge where as age above 56 have a good experience and better knowledge except some who have limited knowledge of folk medicine as they are hereditary healers who specialized in treatment of very few diseases.

According to ours statistical analysis there was no significant relationship (Spearman's correlation coefficient, $r=0.4608$, at $5 \%$ level of significant) correlation was observed between the age of the informant and his knowledge of dosages of medicine.

No significant $\left(\mathrm{X}^{2}\right.$ calculated $=0.49, \mathrm{X}^{2}$ table value $\left.=5.99\right)$ difference was observed between the consumption of medicinal plants for every type of diseases and hesitation to medicate people with herbal 
medicine. Peoples does not hesitate to medicate with herbal medicine as they have accustomed with the used of wild plants (36.6\%) followed by actual experience of the informants $(31.7 \%)$ and confidence of the herbal practioners $(31.7 \%)$. However, traditional healers of the opinion that it varies on individuals regarding the curing of a particular ailment. Herbal medicine are used for all types of primary diseases (36.6\%) followed by some particular diseases $(34.1 \%$ ) and minor diseases $(29.3 \%)$. regarding doses $51.2 \%$ does not have idea about exact doses and only $12.1 \%$ of the informants have exact idea of doses. No significant $\left(\mathrm{X}^{2}\right.$ calculated $2=4.439$, $\mathrm{X}^{2}$ table value $\left.=5.99\right)$ difference was observed between outcome of the treatment and hesitation to medicate people with herbal medicine. It meant that confidence level of the practioner and the result of treatment is not significantly interdependent outcome of the treatment. Regarding the outcome of the treatment age intervals 35 - 45 were doubtful, 46- 55 have mixed type of opinion and age above 56 have greater confidence of their dosages of medicine.

All preparation is more or less the same way. Several species are believed to have medicinal properties and are commonly eaten by those villagers seeking therapeutically benefits. The mode of preparation falls under 16 categories (Table 5) in which decoction mode is the most prepared (20.79\%) and the least in Ash and extraction. In case of climbers, trees and herbs the major mode of preparation is decoction whereas in cultivated it is added to meals and concoction in shrubs.

Regarding the type of ailments 18 types including miscellaneous are used for treatment. Of the 205 therapeutic applications described in the table Gastrointestinal ailments constitutes the highest ( $13.17 \%)$ followed by Respiratory system disorder (10.73\%),Inflammatory problems, Dermatological problems andgynecological problems by (9.75\%); Tonic(7.31\%); First aids (5.85\%); Miscellaneous (5.36\%); Bites, Endocrinology problem and Urinary ailments by (4.87\%); Fever (4.39\%);Dental problems (2.43\%); Nervous disorderness (1.95\%); Carminative and Ear and eye problems (1.46\%); CardiovascularandBone fractureby $(0.97 \%)$.

\section{[Insert figure:3]}

In all the growth forms gastrointestinal ailments was the highest cured ailment. Several species where more than $90 \%$ of the manipuris significant took as self medications rather than modern medicine are Cuscuta reflexa, Melothria maderaspatana, Mimosa pudica and Pavetta indica boiled and the decoction is drunk to cure jaundice. Another such case is dog and snake bites where Amaranthus viridis, Mikania cordata, Argyreia nervosa, Bambusanutansand Arundo donaxwere effectively used by herbals practitioners. Minor ailments like stomach ulcer people simply boiled Benincasa hispida and consumedPhologanthus thyrisiflmis and Solanum surattense. Drymaria cordata is dried and the smoke is inhaled for treatment of asthma and respiratory problems. Species Goniothalamus seoquipedalis and Crassocephalum crepidiodesleaves are simply crushed and applied the cuts and wounds when children got hurt while playing. Stone case of problems is also cure by herbal practioners with great significant.

\section{[Insert figure :4]}

Moreover for urinary problems species like Cissus adanata Roxb, Cissus javanica (Thunb.)S.W, Parthenocissus quinquefolia were effectively used. Diplocyclos palmatus (L.) C. Jeffrey is used for reproductively problems. Some medicinal plants which were used for multiple therapeutic are Oroxylon indicum Vent, Mikania cordata (Burm.f.) B.L. Robinson, Phlogacanthus thyrsiflorus Nees, Allium tuberosum Rottl. ex. Sprang, Tinospora cordifolia Miers ex hook.f. Thong, Curcuma angustifolia Roxb, Allium tuberosum Rottle ex Spreng, Sapindus mukorosii Gaertn and Lygodium cernum L. Most frequently uses of herbal medicine are for bites (dog and snake bites), jaundice, stone case and gastrointestinal disorder were more preferred than modern medications.

There was significant relationship (Spearman correlation coefficient at $5 \%$ level of significance, $r=$ 0.4164. $\alpha=0.05, p=0.3199$ ) correlation was observed between the knowledge of plants on folk medicine and the mode of transfer of traditional knowledge from as most of the peoples in Manipur take herbal medicine for medicinal value(39\%) followed by body of beliefs and concepts (34.1\%) and traditionally accepted trend $(26.8 \%)$.

Most of the traditional healers got their knowledge from their religious beliefs, forefathers, and traditional healers as guru or teachers. Majority of herbal healers learnt mangtak (a superstition where herbal practioners beliefs that information about curing a particular ailments by a medicinal plant is given by god in his dream) $43.9 \%$, followed by forefathers $(24.4 \%)$ and senior herbal practioners as guru $(24.4 \%)$ later others learnt from text based classical knowledge.

Ideally a plant can be regarded as safe if it is used for both food and medicinal purposes. Home remedy is a treatment to cure a disease or ailment that employs certain species, vegetables or other common item. About $85.85 \%$ of the medicinal plants collected are considered as home prepared remedies which are used both as foodstuff and folk medicine. 
These past and current dependence upon plant as source for medicine gives impetus to ethnopharmological studies for medicines their efficacy, safety and drug discovery potentials. Clinical studies with human subjects represent the only assessment of effectiveness and safety that can translate into medical practice, and national or local health policy (Graz et al 2007).

\section{Conclusion}

Traditional heath care practices by the Manipuri's are differ in their historical origin, theoretical basis, diagnostic technique, therapeutic practice and healing methodswith thecomplementary and alternative medicine practices followed in the Indian mainstream. Traditional healers of Manipur were found to play great roles in the primary healthcare systems and curing some diseases with greater success and greater preference from the people than that of modern medications. There is a common cultural understanding regarding spirituality and healing that harbours trusts between the patients and the Maiba and Maibi. The findings revealed herbal remedies have many advantages like easily availability, easier to prepare and in addition to that it can be used home prepared remedies and moreover it was also linked to family influence and traditional, spiritual, dual heath care andsocioeconomic status.

While stereotypical folk medicine in some form of home prepared remedies of treatment of minor illnesses is widely practiced in Manipur. However, most of the knowledge acquired by the local people has been passed on to them by words of mouth from generation to generation.Further research is needed to ascertain the efficacy and safety of several of the practices and herbal formulation used by traditional medicine systems. The study showed that people collect leaves and fruits mostly thereby leaving a space for more survivality of the plants in comparison to that of use of underground plant plants.

Practioners with only one specialization of treatment: i.e treatment a single particular disease is more knowledgeable and dependable, like diabetes, stone case, jaundice, bone fracture etc.Practioners with multifarious disease depend mostly on others knowledgeable persons or bookish knowledge, knowledge acquired for others practioners therefore they do not have deep understanding and experience of treatment with herbs.

The revival of Meetei mayekin recent years and Govt. of Manipur put up the ancient script in school curriculum in replace of Bengali script in 2005, the valuable indigenous knowledge for the future generation for precautionary measures and maintenance of good health from the secrets of these Puyas can be revealed. But, with the declining trend of indigenous herbal healers and few generations are coming forward to adopt folk healing practices as a profession in Manipur. The department of AYUSH and related institutions is actively trying to revitalize Manipuri Local health tradition and folk healing by conducting workshop, training programme and seminars. The challenges are to educate folk healers about their weakness and strengths and to attract young generation to adopt this profession by means of momentary benefits and to preserve both knowledge and biodiversity. It is high time for preservation and promotion of age old traditions of the Meetei community and to integrate the traditional knowledge with the modern medicine for the welfare of the Manipuri and mankind as whole.

\section{Acknowledgements}

The authors are thankful to Head of Department of Life Sciences for facilities. One of the authors (A. Pinokiyo) is thankful to Head of Department of Botany, DM College of Science, Imphal, Manipur for facilities and encouragements.

\section{References:}

[1]. AYUSH. Mainstreaming of AYUSH Systems in the National Health Care Delivery System. New Delhi: Department of Yoga and Naturopathy, Unani, Siddha and Homoeopathy (AYUSH), Ministry of Health and Family Welfare, Government of India. 2003. Bannerman RH (1982). Traditional medicine in modern health care.World Health Forum. 3:8-13.

[3]. Brummitt, R.K. \& Powell C.E. (1992). Authors of Plant Names: a list of authors of scientific Names of Plants, with recommended Standard Forms of Their Names, Including Abbreviations. Royal Botanic Gardens, Kew.

[4]. Ebungohal, L \& Khelchandra, N (1967). (edited volume) Cheitharol Kumbaba, Published by- Manipuri Sahitya Parishad, Imphal, India.

[5]. Clarke, C.B. (1884). Acanthaceae. In: J.D. Hooker (ed.). Flora of British India, Lovell Reeve, London. 4: 492 - 496

[6]. Deb, D.B. (1961a). Acanthaceae, In: Dicotyledonous plants of Manipur territory. Bull. Botanical Survey of India. Vol. 3

[7]. Deb, D.B. (1961b). Monocotyledonous plants of Manipur Territory. Bulletin of Botanical Survey of India, Vol. 3

[8]. Devi, Kh. S., Devi, Y. S. \& Singh, P. K. (2009). A Census on Edible Flowers found in the valley districts of Manipur. J. Econ. Taxon. Bot. 33: 232 - 239 .

[9]. Devi, W.I., Devi, G.S \& and Singh, C.B (2011). Traditional Herbal Medicine Used For the Treatment of Diabetes in Manipur, India. Research Journal of Pharmaceutical, Biological and Chemical Sciences .2 (4): 709-711.

[10]. Devi, Y.N. and Singh, P.K. (2008). Ethnobotany of Verbenaceae in Manipur, Ethnobotany, 20(1\&2):111-114.

[11]. Elangbam, V.D. (2002). Studies of various aspects of wild edible plants of Manipur valley.Ph.D thesis,Manipur University, Manipur.

[12]. Graz, B., Elisabetsky, E. \& Falquet, J. (2007). Beyond the myth of expensive clinical study: Assessment of traditional medicines. Journal of Ethnopharmacology 113: 382-386. 
[13]. Haile, Y. \& Delenasaw, Y. (2007). Traditional medicinal plant knowledge and use by local healers in Sekoru district, Zimma zone, Southwestern Ethiopia. Journal of Ethnobiology andEthnobotany. 3: 24.

[14]. Hamilton, A.C. (2010). Medicinal plants, conservation and livelihoods. Biodiver Conserv. 13: $1477-1517$

[15]. Hiremath, V.T. \& Taranath, T.C (2010). Traditional phytotherapy for snake bites by tribes of Chitradurga District, Karnataka, India. Ethnobot Leaflets, 14: 120-25.

[16]. Hooker, J.D. 1872-1897. Flora of British India, Vol. 1-7, London.

[17]. Isil, S., Fulya, A., Erdem, Y., \& Sinasi, Y. (2004). An ethnobotanical survey of the Beypazari, Ayas, and Gudul district towns of Ankara province (Turkey). Economic botany., 58(4): 705 - 720.

[18]. Jain, S.K. \& Rao, R.R. (1978). A Handbook of Field and Herbarium Methods.Today and Tommorow's Publishers, New Delhi.

[19]. Kanjilal, U.N., Das, A., Kanjilal P.C. \& De, R.N. (1934-1940). Flora of Assam, 4 vols. Govt. of Assam, Govt Press, Shillong, India.

[20]. Khan, H.M. (2005). Study of Ethnomedicinal plants in Thoubal districts of Manipur . Ph.D thesis , Manipur University , Canchipur

[21]. Khumbongmaym, A.D., Khan, M.L. \& Tripathi, R.S. (2005). Ethnomedicinal plants in the sacred groves of Manipur. Indian Journal of Traditional Knowledge. 4(1): 21 - 32.

[22]. Laishram R (2009). Early Meetei History; religion, society and the Manipur Puyas. Akansha Publishing House, and printed at Aryan Enterprises , New Delhi- 110002 (India) ISBN. 978-81- 8370-163-1.

[23]. Lavekar G, Sharma S (2005). 'Republic of India' in WHO Global Atlas of Traditional, Complementary and Alternative Medicine. Text volume, Bodeker G, Ong C, Grundy C, Burford G, Shein K. Kobe, Japan: World Health Organisation Centre for Health Development.

[24]. Levesque, R. (2007). SPSS Programming and Data Management: A guide for SPSS and SAS users, Fourth eds. ISBN- 1568273908.

[25]. Mankazana, E.M. (1979). A case for the traditional healer in South Africa. S. Afr. Med. J., 56: $1003-1007$.

[26]. Martin, G.J. (1995). Ethnobotany: A methods manual. Chapman and Hall, London.

[27\}. Meetei, S.Y. and Singh, P.K. (2007).Survey for Medicinal plants of Thoubal District, Manipur. Flora and Fauna, 13 (2): 355 - 358.

[28]. Meitei, L.B. (2004). Punshirol Shidahidak. Monika printers, Old News Center, Keishampat Keithel, Imphal, Manipur.

[29]. Meyers, N., A.R. Mittermeier., C.G. Mittermeier., A.B. Fonseca \& J. Kent. (2000). Biodiversity hotspots for conservation priorities. Nature 403: 853-858.

[30]. Sanajaoba,N. (2005). Maipur Past and Present, Mittal Publication, Delhi.

[31]. Khelchandra, N. (1969). History of Ancient Manipuri Literature, Manipuri Sahitya Parishad

[32]. Sharma, T.C. (1985). Studies in the Sources of Pre-History of Manipur and Nagaland.in Pandey History of Manipur, Imphal: Manipur University. 13-18

[33]. Singh, P.K., Singh, T.B. (1995). Some medicinal plants of Manipur: an ethnic approach - People

[34]. Singh, H.B., Singh, R.S. \& Sandhu, J.S. (2003). Herbal medicine of Manipur. Daya Publishing House, Delhi, 110035.

[35]. Singh, H.B.K., Singh, P.K and Elangbam, V.D. (1996). Indigenous bio-floklores and practices: Its role in biodiversity conservation in Manipur.J.Hill research 9(2): 359-362.

[36]. Singh, H.B.K. Singh, P.K.and Jain, A. (1997). Ethno-Medico-Biological Studies in Manipur. J. Hill Res. 10(1): 36-38.

[37]. Singh, H.T. (2009). A manual on the medicinal plants of Manipur.Published by Institute of Bioresources and Sustainable Development, Dept. of Biotechnology, Govt. of India. Printed at Sangai offset Printers, Imphal, Manipur. India.

[38]. Singh, P.K and Singh, K.I. (2003). Mother and child health: an ethnobotanical study of the metei community of Manipur state, India. J. econ.taxon.bot.427 (2): 457- 465

[39]. Singh, P.K. \& Singh, B.K (1996). Superstitions in botanical folklore with reference to metei culture. J. Econ. Taxon. Bot Add Ser. 12: $376-372$.

[40]. Singh, P.K. (2002). Medicinal Plants in Manipur, In Environment and Change, Edited by Prof. R.P.Singh, Rajesh Publications, New Delhi, 85-92.

[41]. Singh, P.K. and Singh, K. I. (2003 a). First - Aid Remedies: An Ethno-Medico-Botanical Study of the Meitei Community of Manipur, India. J. Econ. Taxon. Bot. 427 (2) : 466-472

[42]. Singh, P.K. and Singh, K. I. (2003 c). Traditional Technology and Medicinal Knowledge of "Yu"- An Alcoholic Beverage of Meitei Communities of Manipur in Ethnomedicine of North-East India Edited by Dr. Gian Singh, Dr. H.B. Singh and Dr. T.K. Mukherjee, National Institute of Science Communication and Information Resources (NISCAIR), New Delhi, pp.314-326.

[43]. Singh, P.K., Devi, S.P., Devi, K.K., Ningombam, D.S. and Athokpam, P. (2010). Bambusa tulda Roxb. In Manipur State, India: Exploring the local values and commercial implications. Not. Sci. Biol.,Romania, 2 (2): 35-40.

[44]. Singh, P.K., Singh, N.I \& Singh, I.J. (1988). Ethnobotanical studies on wild edible plants in the markets of Manipur-11. J.Econ. Taxon.Bot. 12(1): 113-119.

[45]. Singh, P.K., Singh, T.B. (1995). Some medicinal plants of Manipur: an ethnic approach - People Sci. network 2(1); 39-40

[46]. Singh,H.B.K.Singh, P.K and Jain,A. (1997). Ethno-medico- biological studies in Manipur. J.Hill Res.10 (1); $36-38$

[47]. Singh,I.S., Singh,P.K and Singh, E.J. (2001). Ethnobotanical uses of some pteridophytic plants species in Manipur. Indian fern J.18: 14-17.

[48]. Sinha, S.C 1987. Ethnobotanical study of Manipur. Ph.D thesis,.Manipur University. Manipur

[49]. Sinha, S.C. (1996) Medicinal Plants of Manipur, MASS Publication, Imphal, Manipur.

[50]. Srivastav,P.K., Singh, N, I. \& Singh, T.S. ( 2009). Medicinal food plants of Manipur. Ann. For., 17

[51]. Vedaja, S. (1998). Manipur: Geography and Regional Development. Rajesh publications, New Delhi, India.

[52]. Yumnam, J.Y. \& Tripathi , OP. Traditional knowledge of eating raw plants by the Meetei of Manipur as medicine/ nutrient supplement in their diet. Indian Journal of Traditional Knowldege. Vol. 11(1), January, 2012: 45-50.

[53]. Yumnam, R. S., Devi, CH.O., Abujam, S.S \& Chetia, D. (2012). Study on the Ethnomedicinal System of Manipur. International Journal of Pharmaceutical \& Biological Archives, 3(3): 587-591. 
Table 3: Showing correlation of Knowledge with age, level of education, knowledge of dosages and source of folk medicine of the 41 informants using SPSS ver. 15.

\begin{tabular}{|l|l|l|l|l|}
\hline Parameters & Age of the Informant & Level of Education & $\begin{array}{l}\text { Knowledge on dosages } \\
\text { of ailments }\end{array}$ & $\begin{array}{l}\text { Source of knowledge } \\
\text { on folk medicine }\end{array}$ \\
\hline Knowledge on & $-0.474^{* *}$ & $0.544^{* *}$ & $-0.417^{*}$ & $-0.455^{* *}$ \\
Folk medicine & 0.002 & 0.000 & 0.007 & 0.003 \\
& 41 & 41 & 41 & 41 \\
\hline
\end{tabular}

Figure 2: Showing major types of ailments against the number of plant species used

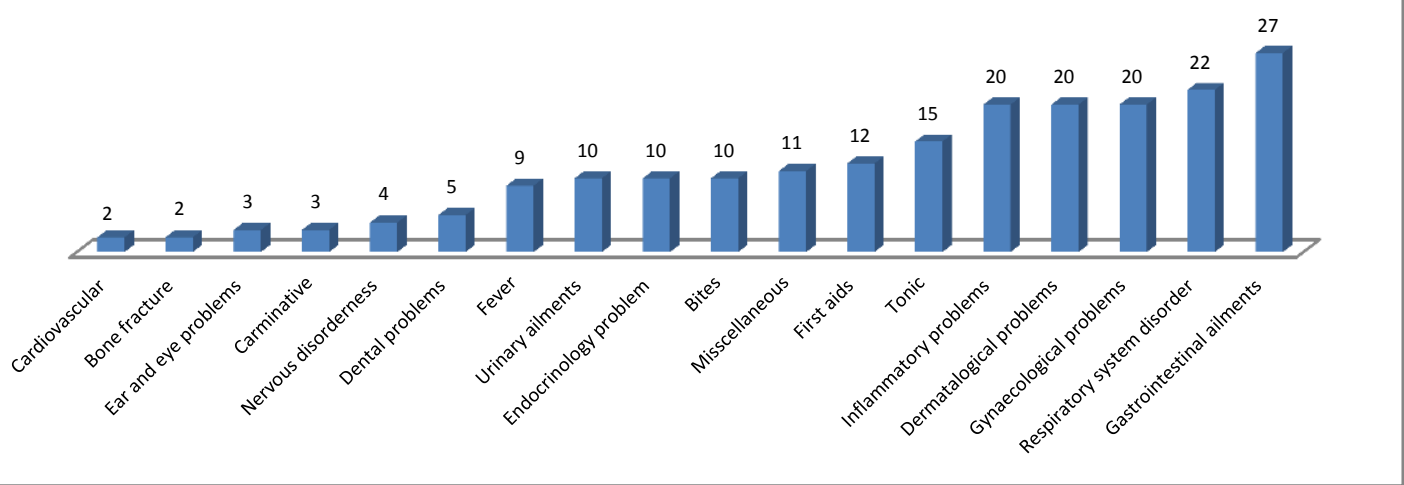

Figure 3: Showing Plant part used against the number of species

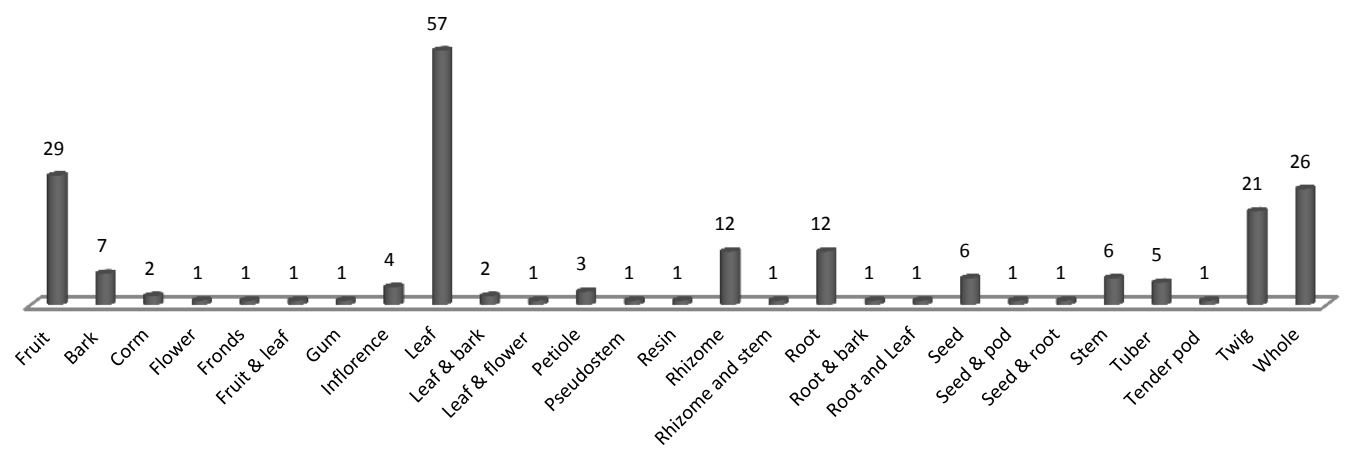

Figure 4: Showing the mode of preparation and administration

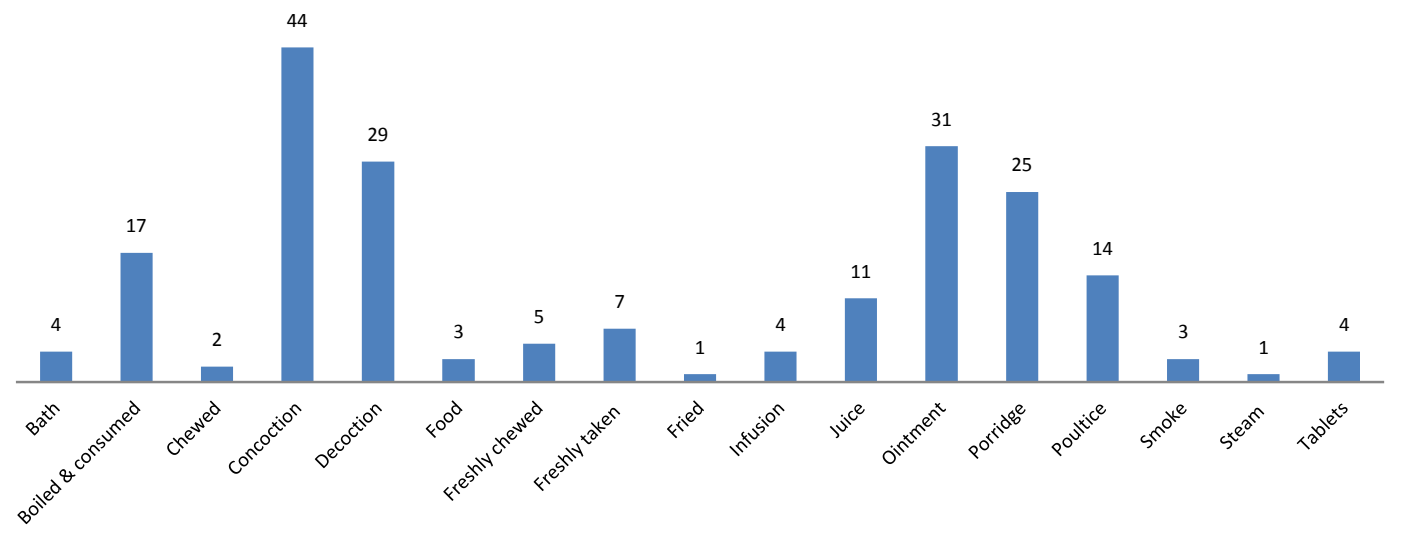


Annexture 1: Table showing the ethno-medicinal uses of plants used by the Meetei community of Manipur, North east India.

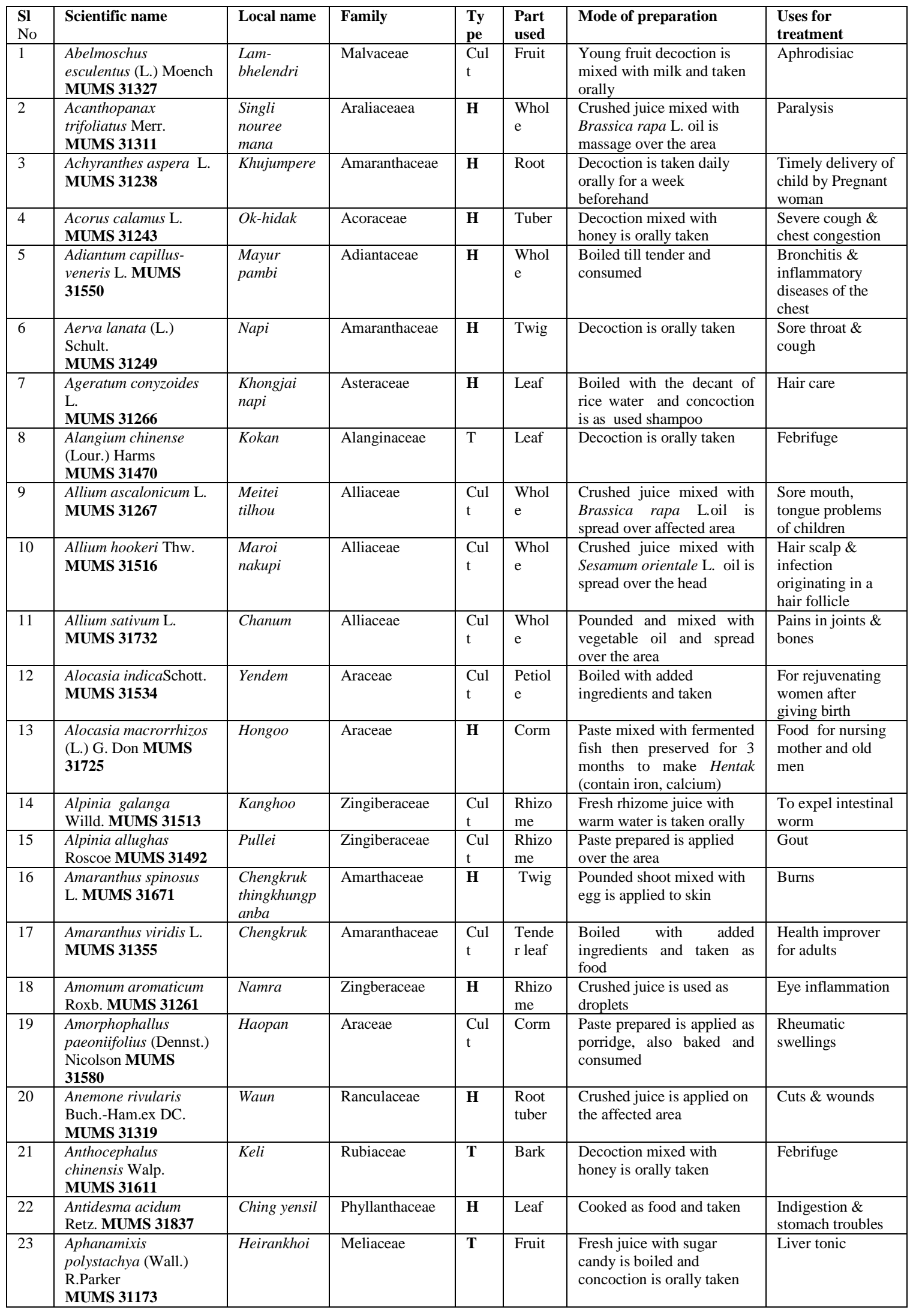


Documentation And Assessment on Knowledge of Ethno-Medicinal Practitioners: A Case Study On






\begin{tabular}{|c|c|c|c|c|c|c|c|}
\hline & $\begin{array}{l}\text { pastoris (L.) Medik. } \\
\text { MUMS } 31881\end{array}$ & & & $\mathrm{t}$ & $\mathrm{e}$ & & \\
\hline 54 & $\begin{array}{l}\text { Carica papaya L. } \\
\text { MUMS } 31853\end{array}$ & Awathabi & Caricaceae & $\begin{array}{l}\mathrm{Cul} \\
\mathrm{t}\end{array}$ & Fruit & $\begin{array}{l}\text { Pounded and paste over the } \\
\text { bitten area }\end{array}$ & Insects \& dog bite \\
\hline 55 & $\begin{array}{l}\text { Cassia occidentalis L. } \\
\text { MUMS } 31290\end{array}$ & Thounam & Fabaceae & $\mathbf{S}$ & Leaf & $\begin{array}{l}\text { Dried powdered leaves with } \\
\text { water is taken orally }\end{array}$ & Diabetes \\
\hline 56 & $\begin{array}{l}\text { Celtis australis L. } \\
\text { MUMS } 31293\end{array}$ & Heikreng & Ulmaceae & $\mathbf{T}$ & Fruit & $\begin{array}{l}\text { Juice with sugar in warm } \\
\text { water is orally taken }\end{array}$ & Jaundice \\
\hline 57 & $\begin{array}{l}\text { Centella asiatica }(\mathrm{L} .) \\
\text { Urb. } \\
\text { MUMS } 31586\end{array}$ & Peruk & Apiaceae & $\mathbf{H}$ & $\begin{array}{l}\text { Whol } \\
\text { e }\end{array}$ & $\begin{array}{l}\text { Chewing and consumption } \\
\text { of the whole plant }\end{array}$ & $\begin{array}{l}\text { Irritation, } \\
\text { inflammation of } \\
\text { throat }\end{array}$ \\
\hline 58 & $\begin{array}{l}\text { Chenopodium album } \\
\text { L. MUMS } 31317\end{array}$ & Monshaobi & $\begin{array}{l}\text { Chenopodiacea } \\
\text { e }\end{array}$ & $\begin{array}{l}\mathrm{Cul} \\
\mathrm{t}\end{array}$ & Twig & $\begin{array}{l}\text { Boiled till tender and } \\
\text { consumed }\end{array}$ & Leucorrhoea \\
\hline 59 & $\begin{array}{l}\text { Ciccus adnata Roxb. } \\
\text { MUMS } 31262\end{array}$ & Kongouyen & Vitaceae & $\begin{array}{l}\mathrm{Cli} \\
\mathrm{m}\end{array}$ & Leaf & $\begin{array}{l}\text { Boiled extract of leaves is } \\
\text { orally taken }\end{array}$ & Urinary stone case \\
\hline 60 & $\begin{array}{l}\text { Cinnamomum } \\
\text { zeylanicum } \text { Blume } \\
\text { MUMS } 31190\end{array}$ & Uchingsha & Lauraceae & $\mathbf{T}$ & $\begin{array}{l}\text { Root } \\
\& \\
\text { bark }\end{array}$ & $\begin{array}{l}\text { Boiled in water and used as } \\
\text { gargle }\end{array}$ & $\begin{array}{l}\text { Bad breath / } \\
\text { mouth freshener }\end{array}$ \\
\hline 61 & $\begin{array}{l}\text { Cissus javanica D.C. } \\
\text { MUMS } 31788\end{array}$ & $\begin{array}{l}\text { Kongyouyen } \\
\text { laba }\end{array}$ & Vitaceae & $\begin{array}{l}\text { Cli } \\
\mathrm{m}\end{array}$ & Leaf & $\begin{array}{l}\text { Boiled extract of leaves is } \\
\text { taken }\end{array}$ & Urinary disorder \\
\hline 62 & $\begin{array}{l}\text { Citrus medica L. } \\
\text { MUMS } 31693\end{array}$ & Heizang & Rutaceae & $\begin{array}{l}\mathrm{Cul} \\
\mathrm{t}\end{array}$ & Fruit & $\begin{array}{l}\text { Cut pieces with decant of } \\
\text { rice is boiled and } \\
\text { concoction is used as } \\
\text { shampoo }\end{array}$ & Hair care \\
\hline 63 & $\begin{array}{l}\text { Citrus limon (L.) Burm } \\
\text {.f. MUMS } 31377\end{array}$ & Champra & Rutaceae & $\begin{array}{l}\mathrm{Cul} \\
\mathrm{t}\end{array}$ & Fruit & $\begin{array}{l}\text { The juice with honey in } \\
\text { warm water is orally taken }\end{array}$ & Cure obesity \\
\hline 64 & $\begin{array}{l}\text { Citrus macroptera } \\
\text { Mont. MUMS } 31280\end{array}$ & Haribob & Rutaceae & $\begin{array}{l}\mathrm{Cul} \\
\mathrm{t}\end{array}$ & Fruit & $\begin{array}{l}\text { The rind of the fruit is used } \\
\text { in the preparation of a } \\
\text { gargle }\end{array}$ & $\begin{array}{l}\text { Enhancing } \\
\text { vocalism by } \\
\text { singers }\end{array}$ \\
\hline 65 & $\begin{array}{l}\text { Clerodendrum } \\
\text { colebrookianum Walp. } \\
\text { MUMS } 31631\end{array}$ & Khuthap & Verbenaceae & $\mathbf{S}$ & Leaf & $\begin{array}{l}\text { Boiled in water adding } \\
\text { ingredients and consumed }\end{array}$ & $\begin{array}{l}\text { Diabetes \& } \\
\text { regulation of } \\
\text { blood pressure }\end{array}$ \\
\hline 66 & $\begin{array}{l}\text { Clerodendrum indicum } \\
\text { Kuntze MUMS } 31847\end{array}$ & $\begin{array}{l}\text { Charoi } \\
\text { utong }\end{array}$ & Verbenaceae & $\mathbf{S}$ & $\begin{array}{l}\text { Whol } \\
\mathrm{e}\end{array}$ & $\begin{array}{l}\text { Decoction mixed with } \\
\text { honey and is orally taken }\end{array}$ & $\begin{array}{l}\text { Menstrual } \\
\text { disorder }\end{array}$ \\
\hline 67 & $\begin{array}{l}\text { Clerodendrun serratum } \\
\text { Moon MUMS } 31830\end{array}$ & $\begin{array}{l}\text { Moirang } \\
\text { khanam }\end{array}$ & Verbenaceae & $\mathbf{S}$ & Leaf & Freshly taken & Stomach disorder \\
\hline 68 & $\begin{array}{l}\text { Coix lacryma-jobi L. } \\
\text { MUMS } 31100\end{array}$ & Chaning & Poaceae & $\mathbf{S}$ & Root & $\begin{array}{l}\text { Root infusion is orally } \\
\text { taken }\end{array}$ & $\begin{array}{l}\text { Menstrual } \\
\text { disorders and as } \\
\text { blood purifier }\end{array}$ \\
\hline 69 & $\begin{array}{l}\text { Colocasia esculenta } \\
\text { (L.) Schott. MUMS } \\
\mathbf{3 1 2 3 5}\end{array}$ & Pan & Araceae & $\begin{array}{l}\mathrm{Cul} \\
\mathrm{t}\end{array}$ & $\begin{array}{l}\text { Petiol } \\
\text { e }\end{array}$ & $\begin{array}{l}\text { Leaf is boiled with fresh } \\
\text { milk and concoction is } \\
\text { orally taken. }\end{array}$ & $\begin{array}{l}\text { Used for } \\
\text { pregnancy to } \\
\text { occur / conceived }\end{array}$ \\
\hline 70 & $\begin{array}{l}\text { Commelina } \\
\text { benghalensis } \mathrm{L} . \\
\text { MUMS } 31600\end{array}$ & $\begin{array}{l}\text { Wangdem } \\
\text { khoibi }\end{array}$ & Commelinaceae & $\mathbf{H}$ & $\begin{array}{l}\text { Whol } \\
\text { e }\end{array}$ & $\begin{array}{l}\text { Crushed juice is applied } \\
\text { over the surface }\end{array}$ & Burns \\
\hline 71 & $\begin{array}{l}\text { Convolvulus arvensis } \\
\text { L. MUMS } 31505\end{array}$ & Uri & Convolvulaceae & $\begin{array}{l}\mathrm{Cli} \\
\mathrm{m}\end{array}$ & Root & Crushed juice & Purgative \\
\hline 72 & $\begin{array}{l}\text { Conyza japonica Less. } \\
\text { MUMS } 31790\end{array}$ & $\begin{array}{l}\text { Terapaibi } \\
\text { manbi }\end{array}$ & Asteraceae & $\mathbf{H}$ & Leaf & $\begin{array}{l}\text { Crushed leaves is applied } \\
\text { over the surface }\end{array}$ & Scabies \\
\hline 73 & $\begin{array}{l}\text { Cordia grandis Roxb. } \\
\text { MUMS } 31658\end{array}$ & Lamuk & Boraginaceae & $\mathbf{T}$ & Fruit & Decoction is orally taken & Urinary infections \\
\hline 74 & $\begin{array}{l}\text { Coriandrum sativum L. } \\
\text { MUMS } 31512\end{array}$ & Phadigom & Apiaceae & $\begin{array}{l}\mathrm{Cul} \\
\mathrm{t}\end{array}$ & $\begin{array}{l}\text { Petiol } \\
\text { e }\end{array}$ & $\begin{array}{l}\text { Crushed juice with hot } \\
\text { water is orally taken }\end{array}$ & Hiccough \\
\hline 75 & $\begin{array}{l}\text { Costus speciosus (J. } \\
\text { Koenig) Sm. } \\
\text { MUMS } 31795\end{array}$ & $\begin{array}{l}\text { Khongban } \\
\text { takhelli }\end{array}$ & Zingiberaceae & $\mathbf{H}$ & $\begin{array}{l}\text { Rhizo } \\
\text { me } \\
\text { and } \\
\text { stem }\end{array}$ & $\begin{array}{l}\text { Boiled in water with added } \\
\text { sugar candy and concoction } \\
\text { is taken orally }\end{array}$ & Tonic for kidney \\
\hline 76 & $\begin{array}{l}\text { Crassocephalum } \\
\text { crepidioides(Benth.) S. } \\
\text { MooreMUMS } \mathbf{3 1 3 8 8}\end{array}$ & Terapaibi & Asteraceae & $\mathbf{H}$ & Leaf & $\begin{array}{l}\text { Crushed leaves applied to } \\
\text { the cuts area }\end{array}$ & Antiseptic \\
\hline 77 & $\begin{array}{l}\text { Cucumis sativus L. } \\
\text { MUMS } 31816\end{array}$ & Thabi & Cucurbitaceae & $\begin{array}{l}\mathrm{Cul} \\
\mathrm{t}\end{array}$ & Fruit & $\begin{array}{l}\text { Freshly or boiled with } \\
\text { water with a pinch of sugar } \\
\text { consumed }\end{array}$ & Stomach ulcer \\
\hline 78 & $\begin{array}{l}\text { Cucurbita maxima } \\
\text { Lam. MUMS } 31884\end{array}$ & Mairel & Cucurbitaceaea & $\begin{array}{l}\mathrm{Cul} \\
\mathrm{t}\end{array}$ & $\begin{array}{l}\text { Tende } \\
\mathrm{r} \text { twig }\end{array}$ & $\begin{array}{l}\text { Pounded and is applied } \\
\text { over the surface }\end{array}$ & Antipyretic \\
\hline 79 & $\begin{array}{l}\text { Curcuma angustifolia } \\
\text { Roxb. MUMS } 31599\end{array}$ & Yaipan & Zingiberaceae & $\begin{array}{l}\mathrm{Cul} \\
\mathrm{t}\end{array}$ & $\begin{array}{l}\text { Rhizo } \\
\text { me }\end{array}$ & Boiled and consumed & Expectorant \\
\hline 80 & $\begin{array}{l}\text { Curcuma caesia } \text { Roxb. } \\
\text { MUMS } 31562\end{array}$ & Yaimu & Zingiberaceae & $\begin{array}{l}\mathrm{Cul} \\
\mathrm{t}\end{array}$ & $\begin{array}{l}\text { Rhizo } \\
\text { me }\end{array}$ & $\begin{array}{l}\text { The fresh crushed juice } \\
\text { added in water with salt and } \\
\text { taken orally }\end{array}$ & Gastric problems \\
\hline 81 & $\begin{array}{l}\text { Curcuma domestica } \\
\text { Valeton MUMS } 31407\end{array}$ & Yangang & Zingiberaceae & $\begin{array}{l}\mathrm{Cul} \\
\mathrm{t}\end{array}$ & $\begin{array}{l}\text { Rhizo } \\
\text { me }\end{array}$ & $\begin{array}{l}\text { Dried powdered is made } \\
\text { paste and spread over the } \\
\text { area }\end{array}$ & $\begin{array}{l}\text { Burns \& skin } \\
\text { tonic }\end{array}$ \\
\hline 82 & $\begin{array}{l}\text { Cuscuta reflexa Roxb. } \\
\text { MUMS } 31573\end{array}$ & $\begin{array}{l}\text { Uri } \\
\text { hangamapal }\end{array}$ & Convolvulaceae & $\begin{array}{l}\mathrm{Cli} \\
\mathrm{m}\end{array}$ & $\begin{array}{l}\text { Whol } \\
\mathrm{e}\end{array}$ & Decoction is orally taken & Jaundice \\
\hline
\end{tabular}




\begin{tabular}{|c|c|c|c|c|c|c|c|}
\hline 83 & $\begin{array}{l}\text { Cymbopogon citratus } \\
\text { Stapf. MUMS } 31374\end{array}$ & Hoana & Poaceae & $\mathbf{H}$ & $\begin{array}{l}\text { Whol } \\
\text { e }\end{array}$ & $\begin{array}{l}\text { The dried plant is boiled in } \\
\text { water and decoction is } \\
\text { taken orally }\end{array}$ & Stone case. \\
\hline 84 & $\begin{array}{l}\text { Cyperus rotundus L. } \\
\text { MUMS } 31199\end{array}$ & Tingthou & Cyperaceae & $\mathbf{H}$ & $\begin{array}{l}\text { Whol } \\
\mathrm{e}\end{array}$ & $\begin{array}{l}\text { The plant juice mixed with } \\
\text { honey is orally taken }\end{array}$ & $\begin{array}{l}\text { To expel intestinal } \\
\text { worm of children }\end{array}$ \\
\hline 85 & $\begin{array}{l}\text { Dichrocephala } \\
\text { integrifolia (L.f.) } \\
\text { Kuntze } \\
\text { MUMS } 31864 \\
\end{array}$ & Lalukok & Asteraceae & $\mathbf{H}$ & Leaf & $\begin{array}{l}\text { The crushed extract is } \\
\text { applied over affected area }\end{array}$ & Skin infections \\
\hline 86 & $\begin{array}{l}\text { Dillenia indica } \mathrm{L} . \\
\text { MUMS } 31910\end{array}$ & Heigri & Dilleniaceae & $\mathbf{T}$ & $\begin{array}{l}\text { Tende } \\
\mathrm{r} \\
\text { shoot } \\
\end{array}$ & $\begin{array}{l}\text { Decoction is orally taken } \\
\text { twice daily }\end{array}$ & Asthma \\
\hline 87 & $\begin{array}{l}\text { Dioscorea alata L. } \\
\text { MUMS } 31593\end{array}$ & $\mathrm{Haa}$ & Dioscoreaceae & $\begin{array}{l}\mathrm{Cli} \\
\mathrm{m}\end{array}$ & Tuber & $\begin{array}{l}\text { Tubers are boiled and eaten } \\
\text { as food }\end{array}$ & Gonorrhoea \\
\hline 88 & $\begin{array}{l}\text { Dioscorea bulbifera L. } \\
\text { MUMS } 31471\end{array}$ & Laa-haa & Dioscoreaceae & $\begin{array}{l}\mathrm{Cli} \\
\mathrm{m}\end{array}$ & Fruit & Decoction is orally taken & Ulcer \& piles \\
\hline 89 & $\begin{array}{l}\text { Diplocyclos palmatus } \\
\text { (L.) C. Jeffrey } \\
\text { MUMS } 31713\end{array}$ & $\begin{array}{l}\text { Leipungkha } \\
\text { nga } \\
\text { marichatpa }\end{array}$ & Curcubitaceae & $\begin{array}{l}\mathrm{Cli} \\
\mathrm{m}\end{array}$ & Seed & $\begin{array}{l}\text { Powdered and mixed with } \\
\text { steamed Melocanna } \\
\text { bumbusoides fruit is } \\
\text { consumed }\end{array}$ & $\begin{array}{l}\text { To help } \\
\text { conception to } \\
\text { occur \& prevent } \\
\text { miscarriage. }\end{array}$ \\
\hline 90 & $\begin{array}{l}\text { Dipterocarpus } \\
\text { tuberculatus } \text { Roxb. } \\
\text { MUMS } 31944 \\
\end{array}$ & Khangra & $\begin{array}{l}\text { Dipterocarpacea } \\
\mathrm{e}\end{array}$ & $\mathbf{T}$ & Root & $\begin{array}{l}\text { Condensed decoction of } \\
\text { root is applied over the } \\
\text { surface }\end{array}$ & Rheumatism \\
\hline 91 & $\begin{array}{l}\text { Docynia indica } \\
\text { (Colebr.) Decne } \\
\text { MUMS 31188 } \\
\end{array}$ & Heitoop & Rosaceae & $\mathbf{T}$ & Fruit & $\begin{array}{l}\text { Infusion with sugar kept for } \\
\text { two week and orally taken }\end{array}$ & Urinary troubles \\
\hline 92 & $\begin{array}{l}\text { Drymaria cordata (L.) } \\
\text { Roem. \& Schult. } \\
\text { MUMS } 31958\end{array}$ & $\begin{array}{l}\text { Tandal } \\
\text { pambi }\end{array}$ & $\begin{array}{l}\text { Caryophyllacea } \\
\mathrm{e}\end{array}$ & $\mathbf{H}$ & $\begin{array}{l}\text { Whol } \\
\mathrm{e}\end{array}$ & $\begin{array}{l}\text { Dried in sun and smoke is } \\
\text { inhaled }\end{array}$ & $\begin{array}{l}\text { Sinusitis, } \\
\text { respiratory \& } \\
\text { breathing } \\
\text { problems }\end{array}$ \\
\hline 93 & $\begin{array}{l}\text { Duabanga grandiflora } \\
\text { (Roxb.) Walp. } \\
\text { MUMS 31221 }\end{array}$ & Bandarhulla & Sonneratiaceae & $\mathbf{T}$ & Fruit & Juice extract & $\begin{array}{l}\text { Ringworm and } \\
\text { warts }\end{array}$ \\
\hline 94 & $\begin{array}{l}\text { Eclipta alba Hassk } \\
\text { MUMS } 31547\end{array}$ & Uchi sumbal & Malvaceae & $\mathbf{H}$ & Leaf & $\begin{array}{l}\text { Fresh leaves is chewed an } \\
\text { kept for while and spit out }\end{array}$ & $\begin{array}{l}\text { Sore mouth \& } \\
\text { tongue disorder }\end{array}$ \\
\hline 95 & $\begin{array}{l}\text { Elsholtzia communis } \\
\text { (Coll. \& Hemsl.) Diels } \\
\text { MUMS } 31909 \\
\end{array}$ & Lomba & Lamiaceae & $\mathbf{S}$ & $\begin{array}{l}\text { Inflor } \\
\text { ence }\end{array}$ & $\begin{array}{l}\text { The dried inflorence is } \\
\text { dipped in honey overnight } \\
\text { and chewed }\end{array}$ & $\begin{array}{l}\text { Tonsillitis \& } \\
\text { throat trouble }\end{array}$ \\
\hline 96 & $\begin{array}{l}\text { Emblica officinalis } \\
\text { Gaertn. MUMS } 31956\end{array}$ & Heikru & Euphorbiaceae & $\mathbf{T}$ & Fruit & $\begin{array}{l}\text { Infusion mixed with honey } \\
\text { is orally taken }\end{array}$ & Hypertension \\
\hline 97 & $\begin{array}{l}\text { Equisetum debile Roxb. } \\
\text { ex Vaucher MUMS } \\
\mathbf{3 1 2 8 2}\end{array}$ & Laiutong & Equisetaceae & $\mathbf{H}$ & $\begin{array}{l}\text { Whol } \\
\text { e }\end{array}$ & $\begin{array}{l}\text { Plant along with } \\
\text { Phlogacanthus thyrsiformis } \\
\text { Nees are crushed and steam } \\
\text { bath }\end{array}$ & $\begin{array}{l}\text { Aching back \& } \\
\text { arms to get relief } \\
\text { from pain. }\end{array}$ \\
\hline 98 & $\begin{array}{l}\text { Eryngium foetidum L. } \\
\text { MUMS } 31818\end{array}$ & $\begin{array}{l}\text { Awaphadigo } \\
m\end{array}$ & Apiaceae & $\begin{array}{l}\mathrm{Cul} \\
\mathrm{t}\end{array}$ & $\begin{array}{l}\text { Whol } \\
\mathrm{e}\end{array}$ & $\begin{array}{l}\text { Crushed juice diluted with } \\
\text { water and orally taken }\end{array}$ & $\begin{array}{l}\text { Digestive } \\
\text { complaints }\end{array}$ \\
\hline 99 & $\begin{array}{l}\text { Erythrina variegate L. } \\
\text { MUMS } 31112\end{array}$ & $\begin{array}{l}\text { Kurao } \\
\text { angouba }\end{array}$ & Fabaceae & $\mathbf{T}$ & Twig & $\begin{array}{l}\text { Decoction mixed with } \\
\text { honey is orally taken }\end{array}$ & Liver tonic \\
\hline 100 & $\begin{array}{l}\text { Eupatorium } \\
\text { adenophorum Spreng. } \\
\text { MUMS } 31432 \\
\end{array}$ & Japan napi & Asteraceae & $\mathbf{H}$ & Leaf & $\begin{array}{l}\text { Leaf juice is applied on cuts } \\
\text { and injuries for clotting } \\
\text { blood and quick healing }\end{array}$ & Astringent \\
\hline 101 & $\begin{array}{l}\text { Eupatorium } \\
\text { birmanicum DC. } \\
\text { MUMS } 31786 \\
\end{array}$ & Langthrei & Asteraceae & $\mathbf{H}$ & Leaf & $\begin{array}{l}\text { Crushed fresh juice is } \\
\text { taken orally }\end{array}$ & Gastro-enteritis \\
\hline 102 & $\begin{array}{l}\text { Eupatorium odoratum } \\
\text { L. MUMS } 31900\end{array}$ & Kambleirei & Asteraceae & $\mathbf{S}$ & Leaf & $\begin{array}{l}\text { Decoction mixed with } \\
\text { honey is orally taken }\end{array}$ & Gonorrhoea \\
\hline 103 & $\begin{array}{l}\text { Euphorbia hirta L. } \\
\text { MUMS } 31472\end{array}$ & $\begin{array}{l}\text { Pakhangleit } \\
\text { on }\end{array}$ & Euphorbiaceae & $\mathbf{H}$ & $\begin{array}{l}\text { Whol } \\
\text { e }\end{array}$ & $\begin{array}{l}\text { Boiled with Cuminum } \\
\text { cyminum } \text { L. seedsin } \\
\text { waterandis taken orally } \\
\end{array}$ & Stone case \\
\hline 104 & $\begin{array}{l}\text { Ficus benghalensis L. } \\
\text { MUMS } 31229\end{array}$ & Khongnang & Moraceae & $\mathbf{T}$ & Gum & $\begin{array}{l}\text { Gum is applied on the } \\
\text { affected area }\end{array}$ & Boils \\
\hline 105 & $\begin{array}{l}\text { Ficus hispida } \text { L.f } \\
\text { MUMS } 31926\end{array}$ & Ashiheibong & Moraceae & $\mathbf{T}$ & Bark & $\begin{array}{l}\text { Decoction of bark is added } \\
\text { pinch of powdered Piper } \\
\text { nigrum with honey is } \\
\text { orally taken for } 7 \text { days }\end{array}$ & Asthma \\
\hline 106 & $\begin{array}{lr}\text { Ficus } & \text { semicordata } \\
\text { Buch.-Ham } & \text { MUMS } \\
\mathbf{3 1 4 6 8} & \\
\end{array}$ & Heiyit & Moraceae & $\mathbf{T}$ & Bark & $\begin{array}{l}\text { Pounded bark is applied } \\
\text { externally }\end{array}$ & $\begin{array}{l}\text { Pimples \& } \\
\text { cracked skin }\end{array}$ \\
\hline 107 & $\begin{array}{l}\text { Flacourtia jangomas } \\
\text { (Lour.) Raeush. } \\
\text { MUMS } 31677 \\
\end{array}$ & Heitroy & Flacourtiaceae & $\mathbf{T}$ & Fruit & $\begin{array}{l}\text { Fresh fruit is chewed and } \\
\text { kept for sometime }\end{array}$ & $\begin{array}{l}\text { Bleeding gums \& } \\
\text { toothache }\end{array}$ \\
\hline 108 & $\begin{array}{l}\text { Galinsoga parviflora } \\
\text { Cav. MUMS } 31598 \\
\end{array}$ & $\begin{array}{l}\text { Hameng } \\
\text { sampakpi }\end{array}$ & Asteraceae & $\mathbf{H}$ & Leaf & $\begin{array}{l}\text { Decoction mixed with } \\
\text { honey is orally taken }\end{array}$ & $\begin{array}{l}\text { Diarrhoea \& } \\
\text { dysentery }\end{array}$ \\
\hline 109 & $\begin{array}{l}\text { Garcinia penduculata } \\
\text { Roxb MUMS } 31733\end{array}$ & Heibung & Clusiaceae & $\mathrm{T}$ & Fruit & $\begin{array}{l}\text { Boiled in water and the } \\
\text { pulp is applied on affected } \\
\text { area }\end{array}$ & $\begin{array}{l}\text { Gout \& Bone } \\
\text { setting }\end{array}$ \\
\hline
\end{tabular}


Documentation And Assessment on Knowledge of Ethno-Medicinal Practitioners: A Case Study On

\begin{tabular}{|c|c|c|c|c|c|c|c|}
\hline 110 & $\begin{array}{l}\text { Girardinia diversifolia } \\
\text { (Link) Friis MUMS } \\
\mathbf{3 1 4 8 1}\end{array}$ & $\begin{array}{l}\text { Santhak } \\
\text { manbee }\end{array}$ & Apiaceae & $\mathbf{H}$ & Leaf & $\begin{array}{l}\text { Crushed juice is applied } \\
\text { externally to relieve }\end{array}$ & Swollen joints. \\
\hline 111 & $\begin{array}{l}\text { Glycosmis arborea } \\
\text { (Roxb.) DC MUMS } \\
\mathbf{3 1 2 6 3} \\
\end{array}$ & Yong komla & Rutaceae & $\mathbf{T}$ & Fruit & $\begin{array}{l}\text { Juice mixed with honey is } \\
\text { orally taken }\end{array}$ & Jaundice \\
\hline 112 & $\begin{array}{l}\text { Gmelina arborea L. } \\
\text { MUMS } 31957\end{array}$ & Wang & Verbenaceae & $\mathbf{T}$ & Root & $\begin{array}{l}\text { Pounded and applied to the } \\
\text { bitten area }\end{array}$ & Poisonous bites. \\
\hline 113 & $\begin{array}{l}\text { Gnaphalium } \\
\text { uliginosum C.B. Clarke } \\
\text { MUMS } 31474 \\
\end{array}$ & $\begin{array}{l}\text { March } \\
\text { cudweed }\end{array}$ & Asteraceae & $\mathbf{H}$ & Twig & Decoction is used as gargle & Mouth ulcer \\
\hline 114 & $\begin{array}{l}\text { Goniothalamus } \\
\text { sequipedalis Hook.f. \& } \\
\text { Thoms. MUMS } 31363 \\
\end{array}$ & Leikham & Annonaceae & $\mathbf{H}$ & Leaf & $\begin{array}{l}\text { Boiled extract is used to } \\
\text { bath new born child }\end{array}$ & Antiseptic \\
\hline 115 & $\begin{array}{l}\text { Hedychium coronarium } \\
\text { J. Koenig MUMS } \\
\mathbf{3 1 5 9 5} \\
\end{array}$ & $\begin{array}{l}\text { Takhellei } \\
\text { agouba }\end{array}$ & Zingiberaceae & $\mathbf{H}$ & $\begin{array}{l}\text { Rhizo } \\
\text { me }\end{array}$ & $\begin{array}{l}\text { Decoction is used as a } \\
\text { gargle }\end{array}$ & Throat complaints \\
\hline 116 & $\begin{array}{l}\text { Hedychium greenii } \\
\text { W.W. Smith MUMS } \\
\text { 31872 }\end{array}$ & $\begin{array}{l}\text { Takhelli } \\
\text { anganba }\end{array}$ & Zingiberaceae & $\mathbf{H}$ & $\begin{array}{l}\text { Rhizo } \\
\text { me }\end{array}$ & $\begin{array}{l}\text { Decoction is mixed with } \\
\text { honey and orally taken }\end{array}$ & Leucorrhoea \\
\hline 117 & $\begin{array}{l}\text { Hedychium spicatum } \\
\text { Sm. MUMS } 31936\end{array}$ & $\begin{array}{l}\text { Takhelli } \\
\text { hanngamap } \\
\text { an }\end{array}$ & Zingiberaceae & $\mathbf{H}$ & $\begin{array}{l}\text { Rhizo } \\
\text { me }\end{array}$ & Decoction is orally taken & Liver tonic \\
\hline 118 & $\begin{array}{l}\text { Hedyotis auricularia L. } \\
\text { MUMS } 31935\end{array}$ & $\begin{array}{l}\text { Langban } \\
\text { kuokha }\end{array}$ & Rubiaceae & $\mathbf{H}$ & Leaf & Decoction is orally taken & Colic pain \\
\hline 119 & $\begin{array}{l}\text { Hemidesmus indicus } \\
\text { R.Br MUMS } 31417\end{array}$ & $\begin{array}{l}\text { Urikhomtho } \\
\text { kpi }\end{array}$ & Asclepiadaceae & $\begin{array}{l}\text { Cli } \\
\mathrm{m}\end{array}$ & Root & $\begin{array}{l}\text { Dry root is made paste and } \\
\text { applied to the area }\end{array}$ & Rheumatism \\
\hline 120 & $\begin{array}{l}\text { Hibiscus cannabinus } \\
\text { L. MUMS } 31533\end{array}$ & Sougree & Malvaceae & $\begin{array}{l}\mathrm{Cul} \\
\mathrm{t}\end{array}$ & Leaf & $\begin{array}{l}\text { Cooked with added } \\
\text { ingredients for more } \\
\text { flavouring dish and taken as } \\
\text { food }\end{array}$ & $\begin{array}{l}\text { Gastritis \& } \\
\text { constipation }\end{array}$ \\
\hline 121 & $\begin{array}{l}\text { Hibiscus sabdariffa L. } \\
\text { MUMS } 31182\end{array}$ & Silo sougree & Malvaceae & $\begin{array}{l}\mathrm{Cul} \\
\mathrm{t}\end{array}$ & Leaf & $\begin{array}{l}\text { Initial boiling later added } \\
\text { ingredients for more } \\
\text { flavouring dish and taken as } \\
\text { food }\end{array}$ & Purgative \\
\hline 122 & $\begin{array}{l}\text { Holmskioldia } \\
\text { arboretum } \text { Retz. } \\
\text { MUMS } 31334 \\
\end{array}$ & $\begin{array}{l}\text { Kharom } \\
\text { leitshom }\end{array}$ & Verbenaceae & $\mathbf{S}$ & Twig & $\begin{array}{l}\text { Pounded and mixed with oil } \\
\text { and applied to head }\end{array}$ & $\begin{array}{l}\text { Headache \& } \\
\text { dizziness }\end{array}$ \\
\hline 123 & $\begin{array}{l}\text { Houttuynia cordata } \\
\text { Thunb. MUMS } 31617\end{array}$ & Tuningkhok & Sauraceae & $\begin{array}{l}\mathrm{Cul} \\
\mathrm{t}\end{array}$ & $\begin{array}{l}\text { Whol } \\
\mathrm{e}\end{array}$ & $\begin{array}{l}\text { Crushed juice is spread } \\
\text { over the affected area }\end{array}$ & Muscular sprain \\
\hline 124 & $\begin{array}{l}\text { Impatiens balsamina } \mathrm{L} . \\
\text { MUMS } 31946\end{array}$ & Khujang & Balsaminaceae & $\mathbf{H}$ & $\begin{array}{l}\text { Leaf } \\
\& \\
\text { flower }\end{array}$ & $\begin{array}{l}\text { Fresh crushed juice of } \\
\text { leaves and flowers is } \\
\text { applied to the effective area }\end{array}$ & $\begin{array}{l}\text { Reduces the pain } \\
\& \text { poison of } \\
\text { wounds caused by } \\
\text { nails }\end{array}$ \\
\hline 125 & $\begin{array}{l}\text { Ipomoea batatas }(\mathrm{L} .) \\
\text { Lam. MUMS } 31945\end{array}$ & Mangra & Convolvulaceae & $\begin{array}{l}\mathrm{Cul} \\
\mathrm{t}\end{array}$ & Twig & Boiled and consumed & $\begin{array}{l}\text { Promoting } \\
\text { lactation }\end{array}$ \\
\hline 126 & $\begin{array}{l}\text { Ipomoea cairica }(\mathrm{L} .) \\
\text { Sweet MUMS } 31497\end{array}$ & $\begin{array}{l}\text { Uri } \\
\text { hingchabee }\end{array}$ & Convolvulaceae & $\begin{array}{l}\mathrm{Cli} \\
\mathrm{m}\end{array}$ & Leaf & $\begin{array}{l}\text { Crushed juice and smeared } \\
\text { over the infected area }\end{array}$ & $\begin{array}{l}\text { Relieves body } \\
\text { rashes }\end{array}$ \\
\hline 127 & $\begin{array}{l}\text { Iris kumaonensis Auct. } \\
\text { MUMS } 31288\end{array}$ & $\begin{array}{l}\text { Komberei } \\
\text { manbee }\end{array}$ & Iridaceae & $\mathbf{H}$ & $\begin{array}{l}\text { Root } \\
\text { and } \\
\text { Leaf }\end{array}$ & $\begin{array}{l}\text { Crushed juice is applied as } \\
\text { poultice over forehead }\end{array}$ & Antipyretic \\
\hline 128 & $\begin{array}{l}\text { Juglans regia L. } \\
\text { MUMS } 31176\end{array}$ & Heijuga & Juglandaceae & $\mathbf{T}$ & Bark & Pounded bark is chewed & Gum bleeding \\
\hline 129 & $\begin{array}{l}\text { Kaempferia galanga L. } \\
\text { MUMS } 31193\end{array}$ & $\begin{array}{l}\text { Yaithamnam } \\
\text { anbi }\end{array}$ & Zingiberaceae & $\mathrm{H}$ & $\begin{array}{l}\text { Rhizo } \\
\text { me }\end{array}$ & $\begin{array}{l}\text { Decoction mixed with } \\
\text { honey is orally taken }\end{array}$ & $\begin{array}{l}\text { Muscular } \\
\text { strengthening }\end{array}$ \\
\hline 130 & $\begin{array}{l}\text { Lagenaria hispida Ser. } \\
\text { MUMS } 31482\end{array}$ & Khongdrum & Cucurbitaceae & $\begin{array}{l}\mathrm{Cul} \\
\mathrm{t}\end{array}$ & Fruit & $\begin{array}{l}\text { Decoction is mixed with } \\
\text { Brasssica rapa oil and } \\
\text { exposed to sex organ }\end{array}$ & $\begin{array}{l}\text { For easy delivery } \\
\text { of baby }\end{array}$ \\
\hline 131 & $\begin{array}{l}\text { Lagenaria siceraria } \\
\text { (Molina) Standl. } \\
\text { MUMS } 31596 \\
\end{array}$ & Tumba & Curcubitaceae & $\begin{array}{l}\mathrm{Cli} \\
\mathrm{m}\end{array}$ & Fruit & $\begin{array}{l}\text { Boiled with a pinch of } \\
\text { sugar and consumed }\end{array}$ & Leucorrhoea \\
\hline 132 & $\begin{array}{l}\text { Lantana camara L. } \\
\text { MUMS } 31175\end{array}$ & Nongbanlei & Verbenaceae & $\mathbf{S}$ & Leaf & $\begin{array}{l}\text { Crushed juice is applied on } \\
\text { the affected area }\end{array}$ & $\begin{array}{l}\text { Controlling } \\
\text { bleeding in } \\
\text { injuries }\end{array}$ \\
\hline 133 & $\begin{array}{l}\text { Leucas aspera Link } \\
\text { MUMS } 31904\end{array}$ & $\begin{array}{l}\text { Mayang } \\
\text { lembum }\end{array}$ & Lamiaceae & $\mathbf{H}$ & Twig & Cooked with lata fish & Malnutrition \\
\hline 134 & $\begin{array}{l}\text { Ligustrum } \\
\text { indicum(Lour.) Merr. } \\
\text { MUMS 31627 }\end{array}$ & $\begin{array}{l}\text { Ching } \\
\text { kundo }\end{array}$ & Oleaceae & $\mathbf{S}$ & Leaf & $\begin{array}{l}\text { Poultice applied to the } \\
\text { affected area }\end{array}$ & Bruises \\
\hline 135 & $\begin{array}{l}\text { Litsea monopetala Pers. } \\
\text { MUMS } 31778\end{array}$ & Tumitla & Lauraceae & $\mathbf{T}$ & $\begin{array}{l}\text { Leaf } \\
\& \\
\text { bark }\end{array}$ & $\begin{array}{l}\text { Extract \& powdered is } \\
\text { made paste and spread over } \\
\text { the surface }\end{array}$ & Muscular pains \\
\hline 136 & $\begin{array}{l}\text { Litsea sebifera Pers. } \\
\text { MUMS } 31954\end{array}$ & Thang hidak & Lauraceae & $\mathbf{T}$ & $\begin{array}{l}\text { Leaf } \\
\& \\
\text { bark }\end{array}$ & $\begin{array}{l}\text { Juice/ powdered is made } \\
\text { paste and applied over the } \\
\text { affected area }\end{array}$ & Cut and injuries \\
\hline 137 & $\begin{array}{l}\text { Melanorrhoea usitata } \\
\text { Wall. MUMS } 31833 \\
\end{array}$ & Khe-U & Anacardiaceae & $\mathbf{T}$ & Resin & $\begin{array}{l}\text { Spread over the affected } \\
\text { area }\end{array}$ & Leprosy \\
\hline
\end{tabular}


Documentation And Assessment on Knowledge of Ethno-Medicinal Practitioners: A Case Study On

\begin{tabular}{|c|c|c|c|c|c|c|c|}
\hline 138 & $\begin{array}{l}\text { Melastoma } \\
\text { malabathricum } \mathrm{L} . \\
\text { MUMS } 31704\end{array}$ & Yachubi & Melastomaceae & $\mathbf{S}$ & Twig & Freshly chewed & Dental problems \\
\hline 139 & $\begin{array}{l}\text { Melothria } \\
\text { maderaspatana }(\mathrm{L} .) \\
\text { Cogn. MUMS } 31955\end{array}$ & Lamthabi & Cucurbitaceae & $\begin{array}{l}\mathrm{Cli} \\
\mathrm{m}\end{array}$ & $\begin{array}{l}\text { Whol } \\
\text { e }\end{array}$ & Decoction is orally taken & Jaundice \\
\hline 140 & $\begin{array}{l}\text { Mentha spicata L. } \\
\text { MUMS } 31917\end{array}$ & $\begin{array}{l}\text { Nungsi- } \\
\text { hidak }\end{array}$ & Limiaceae & $\mathbf{H}$ & $\begin{array}{l}\text { Whol } \\
\mathrm{e}\end{array}$ & Fresh leaves is consumed & Gastro-enteritis \\
\hline 141 & $\begin{array}{l}\text { Mesua ferrea L. } \\
\text { MUMS } 31776\end{array}$ & Nageshor & Clusiaceae & $\mathbf{T}$ & $\begin{array}{l}\text { Flowe } \\
\mathrm{r}\end{array}$ & Decoction is orally taken & Asthma \\
\hline 142 & $\begin{array}{l}\text { Michelia champaca L. } \\
\text { MUMS } 31224\end{array}$ & Leihow & Magnoliaceae & $\mathbf{T}$ & Leaf & $\begin{array}{l}\text { Decoction is orally taken } \\
\text { with honey }\end{array}$ & Colic \\
\hline 143 & $\begin{array}{l}\text { Mikania cordata } \\
\text { (Burm.f.) B.L. Rob. } \\
\text { MUMS } 31195 \\
\end{array}$ & $\begin{array}{l}\text { Uri } \\
\text { hingchabi }\end{array}$ & Asteraceae & $\begin{array}{l}\mathrm{Cli} \\
\mathrm{m}\end{array}$ & Leaf & Decoction is orally taken & Snake bite \\
\hline 144 & $\begin{array}{l}\text { Millettia } \\
\text { pachycarpaBenth. } \\
\text { MUMS } 31444\end{array}$ & Ngamuyai & Fabaceae & $\mathbf{S}$ & $\begin{array}{l}\text { Stem } \\
\text { and } \\
\text { root }\end{array}$ & $\begin{array}{l}\text { Extract juice is applied over } \\
\text { affected area }\end{array}$ & Scabies \\
\hline 145 & $\begin{array}{l}\text { Mimosa pudica L. } \\
\text { MUMS } 31932\end{array}$ & $\begin{array}{l}\text { Kangphan } \\
\text { ekaithabi }\end{array}$ & Mimosaceae & $\mathbf{H}$ & $\begin{array}{l}\text { Whol } \\
\mathrm{e}\end{array}$ & Decoction is orally taken & Jaundice \\
\hline 146 & $\begin{array}{l}\text { Mirabilis jalapa } \mathrm{L} . \\
\text { MUMS } 31942\end{array}$ & Mukaklei & Nyctaginaceae & $\mathbf{H}$ & Leaf & $\begin{array}{l}\text { Crushed juice is applied } \\
\text { over the surface }\end{array}$ & Bruises \& wounds \\
\hline 147 & $\begin{array}{l}\text { Momordica charantia } \\
\text { L. MUMS } 31396\end{array}$ & $\begin{array}{l}\text { Karot } \\
\text { akabee }\end{array}$ & Curbitaceae & $\begin{array}{l}\mathrm{Cul} \\
\mathrm{t}\end{array}$ & Fruit & $\begin{array}{l}\text { Sliced parts are fried in } \\
\text { Brassica rapa oil and } \\
\text { consumed }\end{array}$ & $\begin{array}{l}\text { Controlling } \\
\text { diabetes }\end{array}$ \\
\hline 148 & $\begin{array}{l}\text { Mucuna pruriens (L.) } \\
\text { DC. MUMS } 31416\end{array}$ & Samu hawai & Fabaceae & $\begin{array}{l}\text { Cli } \\
\mathrm{m}\end{array}$ & $\begin{array}{l}\text { Seed } \\
\& \text { pod }\end{array}$ & $\begin{array}{l}\text { Powdered mixed with milk } \\
\text { is orally taken }\end{array}$ & Aphrodisiac \\
\hline 149 & $\begin{array}{l}\text { Musa x paradisiaca } \mathrm{L} . \\
\text { MUMS } 31731\end{array}$ & Laphu & Musaceae & $\mathbf{H}$ & $\begin{array}{l}\text { Pseud } \\
\text { ostem }\end{array}$ & $\begin{array}{l}\text { Boiled till tender and orally } \\
\text { taken }\end{array}$ & Purgative \\
\hline 150 & $\begin{array}{l}\text { Muscari commutatum } \\
\text { Vent MUMS } 31551\end{array}$ & Lam napi & Hyacinthaceae & $\mathbf{H}$ & Leaf & $\begin{array}{l}\text { Crushed juice diluted is } \\
\text { orally taken }\end{array}$ & Cough \\
\hline 151 & $\begin{array}{l}\text { Mussaenda frondosa L. } \\
\text { MUMS } 31858\end{array}$ & Hanulei & Rubiaceae & $\begin{array}{l}\mathrm{Cli} \\
\mathrm{m}\end{array}$ & Leaf & $\begin{array}{l}\text { Paste of the crushed leaves } \\
\text { is applied to the broken part }\end{array}$ & $\begin{array}{l}\text { Healing bone } \\
\text { fracture }\end{array}$ \\
\hline 152 & $\begin{array}{l}\text { Mussaenda roxburghii } \\
\text { Hook.f. MUMS } \mathbf{3 1 1 0 7}\end{array}$ & Hanulei & Rubiaceae & $\begin{array}{l}\text { Cli } \\
\mathrm{m}\end{array}$ & Bark & $\begin{array}{l}\text { Pounded bark juice is } \\
\text { applied over the bitten area }\end{array}$ & Snake bite \\
\hline 153 & $\begin{array}{l}\text { Ophiopogon } \\
\text { intermedius D.Don } \\
\text { MUMS 31220 }\end{array}$ & $\begin{array}{l}\text { Ching } \\
\text { charot }\end{array}$ & Haemodoraceae & $\begin{array}{l}\mathrm{Cli} \\
\mathrm{m}\end{array}$ & Tuber & Decoction is orally taken & Dropsy \\
\hline 154 & $\begin{array}{l}\text { Opuntia dillenii Haw. } \\
\text { MUMS } 31616\end{array}$ & Meipokpi & Cactaceae & $\mathbf{H}$ & Stem & $\begin{array}{l}\text { The tip of stem is cut and } \\
\text { made a hole in the middle } \\
\text { and the affected finger is } \\
\text { inserted into it }\end{array}$ & $\begin{array}{l}\text { Inflammation of } \\
\text { fingers due to } \\
\text { washing or } \\
\text { cleaning of clothes } \\
\text { and utensils. }\end{array}$ \\
\hline 155 & $\begin{array}{l}\text { Oroxylum indicum } \\
\text { Vent MUMS } 31223\end{array}$ & Shamba & Bignoniaceae & $\mathbf{T}$ & Bark & $\begin{array}{l}\text { The inner bark is peel off } \\
\text { upwards and made into } \\
\text { paste and applied on the } \\
\text { anus }\end{array}$ & Piles \\
\hline 156 & $\begin{array}{l}\text { Osbeckia stellata Wall. } \\
\text { MUMS } 31333\end{array}$ & $\begin{array}{l}\text { Nura } \\
\text { khongjomba }\end{array}$ & Melastomaceae & $\mathbf{S}$ & Twig & $\begin{array}{l}\text { Crushed juice mixed with } \\
\text { honey is orally taken }\end{array}$ & $\begin{array}{l}\text { Menstrual } \\
\text { complaints }\end{array}$ \\
\hline 157 & $\begin{array}{l}\text { Oxalis corniculata } \mathrm{L} . \\
\text { MUMS } 31728\end{array}$ & Yensil & Oxalidaceae & $\mathbf{H}$ & $\begin{array}{l}\text { Whol } \\
\mathrm{e}\end{array}$ & $\begin{array}{l}\text { Cut pieces is mixed with } \\
\text { honey is taken }\end{array}$ & $\begin{array}{l}\text { Tonic for heart } \\
\text { disease }\end{array}$ \\
\hline 158 & $\begin{array}{l}\text { Paederia foetida } \mathrm{L} . \\
\text { MUMS } 31406\end{array}$ & Oinum & Rubiaceae & $\begin{array}{l}\text { Cli } \\
\mathrm{m}\end{array}$ & Twig & $\begin{array}{l}\text { Crushed extract and paste is } \\
\text { applied at the broken part }\end{array}$ & $\begin{array}{l}\text { Enhanced healing } \\
\text { bone fracture }\end{array}$ \\
\hline 159 & $\begin{array}{l}\text { Paris polyphylla } \mathrm{Sm} . \\
\text { MUMS } 31212\end{array}$ & Haopan & Liliaceae & $\mathbf{H}$ & $\begin{array}{l}\text { Rhizo } \\
\text { me }\end{array}$ & Decoction is orally taken & Anthelmintic \\
\hline 160 & $\begin{array}{l}\text { Parkia roxburghii } \\
\text { G.Don MUMS } 31165\end{array}$ & Yongchak & Mimosaceae & $\mathbf{T}$ & $\begin{array}{l}\text { Tende } \\
\mathrm{r} \text { pod }\end{array}$ & $\begin{array}{l}\text { Freshly or boiled and } \\
\text { consumed }\end{array}$ & Constipation \\
\hline 161 & $\begin{array}{l}\text { Parthenocissus } \\
\text { quinquefolia }(\mathrm{L} .) \\
\text { Planch. MUMS } 31174 \\
\end{array}$ & Angurmanbi & Vitaceae & $\begin{array}{l}\mathrm{Cli} \\
\mathrm{m}\end{array}$ & Fruit & $\begin{array}{l}\text { Extract juice with sugar } \\
\text { candy is orally taken }\end{array}$ & Liver tonic \\
\hline 162 & $\begin{array}{l}\text { Passiflora edulis Sims. } \\
\text { MUMS } 31119\end{array}$ & Sitaphal & Passifloraceae & $\begin{array}{l}\mathrm{Cli} \\
\mathrm{m}\end{array}$ & Leaf & $\begin{array}{l}\text { Fresh leaves boiled with } \\
\text { sugar candy and } n \text { orally } \\
\text { taken }\end{array}$ & Dysentery \\
\hline 163 & $\begin{array}{l}\text { Pavetta indica L. } \\
\text { MUMS } 31357\end{array}$ & $\begin{array}{l}\text { Nongmangk } \\
\text { ha asinba }\end{array}$ & Rubiaceae & $\mathrm{S}$ & Leaf & $\begin{array}{l}\text { Boiled with sugar candy } \\
\text { and the concoction is orally } \\
\text { taken }\end{array}$ & Jaundice \\
\hline 164 & $\begin{array}{l}\text { Phlogacanthus } \\
\text { thyrsiformis } \text { Nees } \\
\text { MUMS } 31222 \\
\end{array}$ & $\begin{array}{l}\text { Nongmangk } \\
\text { ha }\end{array}$ & Acanthaceae & $\mathbf{S}$ & Twig & $\begin{array}{l}\text { Boiled with water and } \\
\text { steam is inhale through a } \\
\text { small hole }\end{array}$ & Cough \& fever \\
\hline 165 & $\begin{array}{l}\text { Piper longum L. } \\
\text { MUMS } 31262\end{array}$ & Uchi thi & Piperaceae & $\begin{array}{l}\text { Cli } \\
\mathrm{m}\end{array}$ & Fruit & $\begin{array}{l}\text { Powdered mixed with milk } \\
\text { is orally taken }\end{array}$ & $\begin{array}{l}\text { Respiratory } \\
\text { problems }\end{array}$ \\
\hline 166 & $\begin{array}{l}\text { Plantago erosa Wall. } \\
\text { MUMS } 31787\end{array}$ & Yempat & Plantaginaceae & $\mathbf{H}$ & Leaf & $\begin{array}{l}\text { Crushed leaves are applied } \\
\text { to the affected area }\end{array}$ & $\begin{array}{l}\text { Muscular sprains } \\
\& \text { swellings }\end{array}$ \\
\hline 167 & $\begin{array}{l}\text { Plumbago zeylanica L. } \\
\text { MUMS } 31637\end{array}$ & Telhidak & Plumbaginaceae & $\mathbf{H}$ & Twig & $\begin{array}{l}\text { Crushed fresh leaf juice is } \\
\text { orally taken }\end{array}$ & $\begin{array}{l}\text { Menstrual } \\
\text { disorder }\end{array}$ \\
\hline 168 & $\begin{array}{l}\text { Prunus persica }(\mathrm{L} .) \\
\text { Batsch MUMS } 31103\end{array}$ & Heikha & Rutaceae & $\mathbf{T}$ & Fruit & $\begin{array}{l}\text { Infusion with sugar kept } \\
\text { for two week and is orally }\end{array}$ & Urinary troubles \\
\hline
\end{tabular}




\begin{tabular}{|c|c|c|c|c|c|c|c|}
\hline & & & & & & taken & \\
\hline 169 & $\begin{array}{l}\text { Psidium guajava L. } \\
\text { MUMS } 31283\end{array}$ & Pungdon & Myrtaceae & $\begin{array}{l}\mathrm{Cul} \\
\mathrm{t}\end{array}$ & $\begin{array}{l}\text { Fruit } \\
\text { \& leaf }\end{array}$ & $\begin{array}{l}\text { Crushed tender leaves juice } \\
\text { with little water is drunk or } \\
\text { the fruit is freshly eaten. }\end{array}$ & Diarrhoea \\
\hline 170 & $\begin{array}{l}\text { Pteris ensiformis Burm. } \\
\text { F. MUMS } 31110\end{array}$ & $\begin{array}{l}\text { Laichangkhr } \\
\text { ang }\end{array}$ & Pteridaceae & $\mathbf{H}$ & $\begin{array}{l}\text { Frond } \\
\mathrm{s}\end{array}$ & $\begin{array}{l}\text { Decoction of the fresh } \\
\text { fronds is orally taken }\end{array}$ & $\begin{array}{l}\text { Glandular } \\
\text { swelling of the } \\
\text { neck }\end{array}$ \\
\hline 171 & $\begin{array}{l}\text { Quercus serrata Thunb. } \\
\text { MUMS } 31207\end{array}$ & Uyung & Fagaceae & $\mathbf{T}$ & Leaf & $\begin{array}{l}\text { The ash obtained by } \\
\text { burning the leaves are } \\
\text { mixed with water until it } \\
\text { turns coffee colour and } \\
\text { taken orally }\end{array}$ & White discharge \\
\hline 172 & $\begin{array}{l}\text { Rhododendron } \\
\text { arboretum Sm. MUMS } \\
\mathbf{3 1 8 6 0}\end{array}$ & $\begin{array}{l}\text { Ching } \\
\text { leihao }\end{array}$ & Eriaceae & $\mathbf{T}$ & Twig & $\begin{array}{l}\text { Decoction is orally taken } \\
\text { before delivering child }\end{array}$ & Easy deliver \\
\hline 173 & $\begin{array}{l}\text { Rhus succedanea } \\
\text { Murray MUMS } 31606\end{array}$ & Heimang & Anarcardiaceae & $\mathbf{T}$ & Seed & $\begin{array}{l}\text { Seed mixed Allium cepa } \\
\text { and sugar candy is boiled in } \\
\text { water and the concotion is } \\
\text { orally taken }\end{array}$ & $\begin{array}{l}\text { Controlling } \\
\text { diabetes }\end{array}$ \\
\hline 174 & $\begin{array}{l}\text { Ricinus communis L. } \\
\text { MUMS } 31607\end{array}$ & Kege & Euphorbiaceae & $\mathbf{S}$ & Root & $\begin{array}{l}\text { Boiled together with } \\
\text { PinusKesiya Royle ex } \\
\text { Gordon leaf, stife of } \\
\text { Nymphaea nouchali } \\
\text { Burm.f. and concoction is } \\
\text { orally taken }\end{array}$ & $\begin{array}{l}\text { Complaints during } \\
\text { pregnancy }\end{array}$ \\
\hline 175 & $\begin{array}{l}\text { Rubus ellipticus Sm. } \\
\text { MUMS } 31369\end{array}$ & $\begin{array}{l}\text { Lam- } \\
\text { hejampet }\end{array}$ & Rosaceae & $\mathbf{S}$ & Leaf & $\begin{array}{l}\text { Fresh tender leaves are } \\
\text { chewed and sap is } \\
\text { swallowed }\end{array}$ & Tongue sores \\
\hline 176 & $\begin{array}{l}\text { Sapindus mukorossi } \\
\text { Gaertn. MUMS } 31301\end{array}$ & Kekru & Sapandiaceae & $\mathbf{T}$ & Fruit & $\begin{array}{l}\text { Fresh foam on stirring the } \\
\text { fruit with water is applied } \\
\text { as poultice }\end{array}$ & $\begin{array}{l}\text { Antipyretic for } \\
\text { children }\end{array}$ \\
\hline 177 & $\begin{array}{l}\text { Schefflera venulosa } \\
\text { (Wight \& Arn.) Harms. } \\
\text { MUMS 31246 }\end{array}$ & Utang & Araliaceae & $\begin{array}{l}\mathrm{Cli} \\
\mathrm{m}\end{array}$ & Root & $\begin{array}{l}\text { Boiled root mixed with rice } \\
\text { and consumed }\end{array}$ & Dropsy \\
\hline 178 & $\begin{array}{l}\text { Schima wallichii } \\
\text { Choisy MUMS } 31241\end{array}$ & Usoi & Theaceae & $\mathbf{T}$ & Fruit & $\begin{array}{l}\text { Fleshly part is stirred along } \\
\text { with little water to form } \\
\text { foam and applied as } \\
\text { poultice }\end{array}$ & Antipyretic \\
\hline 179 & $\begin{array}{l}\text { Scutellaria discolor } \\
\text { Wall. ex Benth. } \\
\text { MUMS } 31325\end{array}$ & Yenakhut & Lamiaceae & $\mathbf{H}$ & $\begin{array}{l}\text { Whol } \\
\mathrm{e}\end{array}$ & Decoction is orally taken & $\begin{array}{l}\text { Controlling } \\
\text { diabetes }\end{array}$ \\
\hline 180 & $\begin{array}{l}\text { Senna tora (L.) Roxb. } \\
\text { MUMS } 31253\end{array}$ & Thaunam & Fabaceae & $\mathrm{S}$ & $\begin{array}{l}\text { Youn } \\
\text { g twig }\end{array}$ & $\begin{array}{l}\text { Boiled and pounded and } \\
\text { applied as porridge }\end{array}$ & Cuts and wounds \\
\hline 181 & $\begin{array}{l}\text { Sesamum indicum L. } \\
\text { MUMS } 31239\end{array}$ & $\begin{array}{l}\text { Thoiding } \\
\text { amuba }\end{array}$ & Pedaliaceae & $\mathrm{H}$ & Seed & $\begin{array}{l}\text { Crushed seed oil is applied } \\
\text { on a cotton and applied on } \\
\text { head }\end{array}$ & $\begin{array}{l}\text { To relieve acute } \\
\text { headache and } \\
\text { dizziness. }\end{array}$ \\
\hline 182 & $\begin{array}{l}\text { Sida rhombifolia L. } \\
\text { MUMS } 31230\end{array}$ & Uhan & Malvaceae & $\mathrm{S}$ & Root & $\begin{array}{l}\text { Mixture of powdered root, } \\
\text { sugar, fresh milk and pure } \\
\text { ghee is orally taken }\end{array}$ & $\begin{array}{l}\text { For pregnancy to } \\
\text { happen/ } \\
\text { Conceived }\end{array}$ \\
\hline 183 & $\begin{array}{l}\text { Smilax zeylanica L. } \\
\text { MUMS } 31348\end{array}$ & Keishum & Liliaceae & $\begin{array}{l}\mathrm{Cli} \\
\mathrm{m}\end{array}$ & Twig & $\begin{array}{l}\text { Crushed mixed with } \\
\text { vegetable oil is applied as } \\
\text { poultice }\end{array}$ & $\begin{array}{l}\text { Rheumatic } \\
\text { swellings }\end{array}$ \\
\hline 184 & $\begin{array}{l}\text { Solanum anguivi Lam. } \\
\text { MUMS } 31441\end{array}$ & $\begin{array}{l}\text { Leipung } \\
\text { khanga }\end{array}$ & Solanaceae & $\mathbf{S}$ & $\begin{array}{l}\text { Fresh } \\
\text { Leaf }\end{array}$ & $\begin{array}{l}\text { Crushed juice mixed with } \\
\text { honey is oral taken }\end{array}$ & $\begin{array}{l}\text { Sore mouth \& } \\
\text { tongue disorder }\end{array}$ \\
\hline 185 & $\begin{array}{l}\text { Solanum surattense } \\
\text { Burm.f. MUMS } 31300\end{array}$ & Singkhang & Solanaceae & $\mathbf{H}$ & Seed & $\begin{array}{l}\text { Dried and burn in charcoal } \\
\text { and smoke is allowed to } \\
\text { enter mouth }\end{array}$ & $\begin{array}{l}\text { Toothache \& anti- } \\
\text { asthmatic }\end{array}$ \\
\hline 186 & $\begin{array}{l}\text { Solanum torvum } \mathrm{Sw} . \\
\text { MUMS } 31200\end{array}$ & $\begin{array}{l}\text { Shing } \\
\text { khangga }\end{array}$ & Solanaceae & $\mathbf{S}$ & Fruit & $\begin{array}{l}\text { Crushed juice mixed with } \\
\text { honey is orally taken }\end{array}$ & Tonsillitis \\
\hline 187 & $\begin{array}{l}\text { Spilanthes paniculata } \\
\text { Wall ex DC. MUMS } \\
\mathbf{3 1 3 8 7}\end{array}$ & Manjareng & Asteraceae & $\mathrm{H}$ & $\begin{array}{l}\text { Inflor } \\
\text { ence }\end{array}$ & Freshly chew & Toothache \\
\hline 188 & $\begin{array}{l}\text { Spondias pinnata(L.f.) } \\
\text { Kurz MUMS } 31366\end{array}$ & Heining & Anacardiaceae & $\mathbf{T}$ & Leaf & $\begin{array}{l}\text { Crushed juice is applied in } \\
\text { drops }\end{array}$ & Ear-ache \\
\hline 189 & $\begin{array}{l}\text { Stephania japonica } \\
\text { (Thunb.) Miers. } \\
\text { MUMS 31411 }\end{array}$ & $\begin{array}{l}\text { Thangga uri } \\
\text { angouba }\end{array}$ & $\begin{array}{l}\text { Menispermacea } \\
\text { e }\end{array}$ & $\begin{array}{l}\mathrm{Cli} \\
\mathrm{m}\end{array}$ & Tuber & $\begin{array}{l}\text { Crushed juice is applied as } \\
\text { poultice over fore head }\end{array}$ & Antipyretic \\
\hline 190 & $\begin{array}{l}\text { Swertia chirata } \text { C.B. } \\
\text { Clarke MUMS } 31398\end{array}$ & Chirata & Gentianceae & $\mathbf{H}$ & $\begin{array}{l}\text { Whol } \\
\mathrm{e}\end{array}$ & Decoction is orally taken & Gastro-enteritis \\
\hline 191 & $\begin{array}{l}\text { Terminalia citrina } \\
\text { Roxb. MUMS } 31877\end{array}$ & Manahi & Combretaceae & $\mathbf{T}$ & Fruit & Decoction is orally taken & $\begin{array}{l}\text { Controlling } \\
\text { diabetes }\end{array}$ \\
\hline 192 & $\begin{array}{l}\text { Thalictrum foliolosum } \\
\text { DC. MUMS } 31359\end{array}$ & Kharuri & Ranunculaceae & $\mathbf{H}$ & Root & $\begin{array}{l}\text { Decoction is taken with } \\
\text { honey orally }\end{array}$ & Febrifuge \\
\hline 193 & $\begin{array}{l}\text { Thunbergia alata Sims } \\
\text { MUMS } 31404\end{array}$ & $\begin{array}{l}\text { Sambal } \\
\text { sana khudop }\end{array}$ & Acanthaceae & $\begin{array}{l}\mathrm{Cli} \\
\mathrm{m}\end{array}$ & Leaf & $\begin{array}{l}\text { Poultice is mixed with the } \\
\text { bee hive mud and applied } \\
\text { over forehead }\end{array}$ & $\begin{array}{l}\text { Relief from acute } \\
\text { headache }\end{array}$ \\
\hline 194 & Thunbergia grandiflora & Sambal & Acanthaceae & Cli & Leaf & Decoction is orally taken & Stomach \\
\hline
\end{tabular}


Documentation And Assessment on Knowledge of Ethno-Medicinal Practitioners: A Case Study On

\begin{tabular}{|c|c|c|c|c|c|c|c|}
\hline & Roxb. MUMS 31394 & khudop & & $\mathrm{m}$ & & & complaints \\
\hline 195 & $\begin{array}{l}\text { Tinospora cordifolia } \\
\text { Miers MUMS } \mathbf{3 1 7 0 3}\end{array}$ & $\begin{array}{l}\text { Ningthouko } \\
\text { ngli }\end{array}$ & $\begin{array}{l}\text { Menispermacea } \\
\mathrm{e}\end{array}$ & $\begin{array}{l}\mathrm{Cli} \\
\mathrm{m}\end{array}$ & Leaf & Boiled and consumed & $\begin{array}{l}\text { Menstrual } \\
\text { disorder \& } \\
\text { impotency }\end{array}$ \\
\hline 196 & $\begin{array}{l}\text { Tithonia diversifolia A. } \\
\text { Gray MUMS } 31379\end{array}$ & $\begin{array}{l}\text { Lam } \\
\text { numetlei }\end{array}$ & Asteraceae & $\mathbf{S}$ & $\begin{array}{l}\text { Inflor } \\
\text { escen } \\
\text { ce }\end{array}$ & $\begin{array}{l}\text { Pounded and spread over } \\
\text { the affected area }\end{array}$ & Wounds \& bruises \\
\hline 197 & $\begin{array}{l}\text { Toona ciliata } \text { M. } \\
\text { Roem. MUMS } 31552\end{array}$ & Tairen & Meliaceae & $\mathbf{T}$ & Leaf & $\begin{array}{l}\text { Boiled in water and take } \\
\text { bath }\end{array}$ & Skin diseases \\
\hline 198 & $\begin{array}{l}\text { Tridax procumbens } \mathrm{L} . \\
\text { MUMS } 31405\end{array}$ & $\begin{array}{l}\text { Mayang } \\
\text { napi }\end{array}$ & Asteraceae & $\mathbf{H}$ & Leaf & $\begin{array}{l}\text { Crushed juice is used as } \\
\text { droplets }\end{array}$ & Catarrh \\
\hline 199 & $\begin{array}{l}\text { Vitex negundo L. } \\
\text { MUMS } 31363\end{array}$ & Urishibi & Verbenaceae & $\mathbf{S}$ & $\begin{array}{l}\text { Tende } \\
\mathrm{r} \text { leaf }\end{array}$ & Freshly taken & Gastro-enteritis \\
\hline 200 & $\begin{array}{l}\text { Wendlandia tinctoria } \\
\text { DC. MUMS } 31337\end{array}$ & $\begin{array}{l}\text { Pheija } \\
\text { ammom }\end{array}$ & Rubiaceae & $\mathbf{T}$ & $\begin{array}{l}\text { Inflor } \\
\text { escen } \\
\text { ce }\end{array}$ & Freshly taken & Gastro-enteritis \\
\hline 201 & $\begin{array}{l}\text { Xylosma longifolia } \\
\text { Clos. MUMS 31452 }\end{array}$ & $\begin{array}{l}\text { Nongleishan } \\
g\end{array}$ & Flacourtiaceae & $\mathbf{T}$ & $\begin{array}{l}\text { Fresh } \\
\text { leaf }\end{array}$ & $\begin{array}{l}\text { Boiled till reduces } 1 / 3 \text { of } \\
\text { the initial volume and bath }\end{array}$ & Scabies \\
\hline 202 & $\begin{array}{l}\text { Zanthoxylum } \\
\text { acanthopodium DC. } \\
\text { MUMS } 31410\end{array}$ & Mukthrubi & Rutaceae & $\mathbf{S}$ & Twig & $\begin{array}{l}\text { Crushed juice mixed with } \\
\mathrm{CaCO}_{3} \text { is applied over the } \\
\text { area }\end{array}$ & Warts \\
\hline 203 & $\begin{array}{l}\text { Zanthoxylum rhetsa } \\
\text { (Roxb.) DC. } \\
\text { MUMS } 31356\end{array}$ & Naoseknum & Rutaceae & $\mathbf{T}$ & Leaf & $\begin{array}{l}\text { Decoction is taken orally } \\
\text { taken }\end{array}$ & Jaundice \\
\hline 204 & $\begin{array}{l}\text { Zehneria scabra }(\mathrm{L} .) \\
\text { Sonder MUMS } 31351\end{array}$ & Lam thabi & Cucurbitaceae & $\begin{array}{l}\mathrm{Cli} \\
\mathrm{m}\end{array}$ & $\begin{array}{l}\text { Whol } \\
\text { e }\end{array}$ & $\begin{array}{l}\text { Decoction is taken orally } \\
\text { taken }\end{array}$ & Jaundice \\
\hline 205 & $\begin{array}{l}\text { Zingiber officinale } \\
\text { Roscoe MUMS } 33310\end{array}$ & Sing & Zingiberaceae & $\begin{array}{l}\mathrm{Cul} \\
\mathrm{t}\end{array}$ & $\begin{array}{l}\text { Rhizo } \\
\text { me }\end{array}$ & $\begin{array}{l}\text { Decoction is mixed with } \\
\text { Brassica rapa L. oil \& curd } \\
\text { and orally taken }\end{array}$ & $\begin{array}{l}\text { Menstrual } \\
\text { disorder }\end{array}$ \\
\hline
\end{tabular}

Annexure 2: Table showing do and don'ts of eating food plants accordingly to the season and its consequences

\begin{tabular}{|c|c|c|c|}
\hline Months & Local Name & Edible plants and parts not be taken & Consequences \\
\hline Mid Apr - mid May & Sajibu & $\begin{array}{l}\text { Musa paradisiacal L. (Laphu) pesudostem and inflorescence } \\
\text { Gnaphalium luteo-album } \mathrm{L} \text {. }\end{array}$ & $\begin{array}{l}\text { Less strength and } \\
\text { complexion }\end{array}$ \\
\hline Mid May - mid Jun & Kalen & $\begin{array}{l}\text { Hedychium coronarium Koenig (Loklei) \&Alpinia nigra (Gaertn) Burtt. } \\
\text { (Pullei) }\end{array}$ & $\begin{array}{l}\text { Urinary trouble } \\
\text { and } \\
\text { gastroenteritis }\end{array}$ \\
\hline Mid Jun - mid Jul & Inga & $\begin{array}{l}\text { Oenanthe javanica (Blume) DC. ( Komprek) \&Polygonum barbatum L. } \\
\text { (Yellang) }\end{array}$ & Dry cough \\
\hline Mid Jul - mid Aug & Ingel & $\begin{array}{l}\text { Plantago erosa Wall. (Yempat),Pterospermum acerifolium,(Kawkla) } \\
\text { Citus reticulate Blonco. (Komla), Agaricus campestris L. (Chengum) } \\
\& \text { Lactarius princeps } \text { Berk. (Chengum) }\end{array}$ & Urinary trouble \\
\hline Mid Aug - mid Sep & Tawan & $\begin{array}{l}\text { Hedychium coronarium Koenig (Loklei), Alpinia nigra (Gaertn) Burtt. } \\
\text { (Pullei) Sagittaria sagittifolia L. (Koukha) }\end{array}$ & $\begin{array}{l}\text { Skin disease and } \\
\text { nervous problem }\end{array}$ \\
\hline Mid Sep - mid Oct & Langba & $\begin{array}{l}\text { Alocasia indica Schott. (Pangkhok) Leucus aspera Link., Knoxia } \\
\text { roxburghii (Yembum), Pogostemon purpurascens (Tekta) }\end{array}$ & Stomach trouble \\
\hline Mid Oct - mid Nov & Mera & $\begin{array}{l}\text { Cucurbita maxima Duch. (Mairel), Houttuynia cordata Thunb. } \\
\text { (Tokningkok) }\end{array}$ & $\begin{array}{l}\text { Nervous and } \\
\text { stomach troubles }\end{array}$ \\
\hline Mid Nov - mid Dec & Hiyangei & $\begin{array}{l}\text { Brasssica rapa (Hangam), Centella asiatica (L.) Urban (Peruk), } \\
\text { Lentinus conatus Berk. (Uyen) \& Lentinus squarrossulus Mont. (U-yen) }\end{array}$ & $\begin{array}{l}\text { Skin diseases and } \\
\text { gum problems }\end{array}$ \\
\hline Mid Dec - mid Jan & Poinu & $\begin{array}{l}\text { Luffa cylindrica (L.)Roem.(Sebot), Trichosanthes anguina L. (Sebot- } \\
\text { linmanbi) }\end{array}$ & $\begin{array}{l}\text { Gum disease and } \\
\text { weakness }\end{array}$ \\
\hline Mid Jan - mid Feb & Wakching & $\begin{array}{l}\text { Schima wallichii Choisy (Usoi), Teinostachyumm wightii Beddome } \\
\text { (Nat), Cephalostachyum capitatum Munro (Nat) shoots (Soijin), } \\
\text { Psophocarpus tetragonolobus DC. (Tengnoumanbi). }\end{array}$ & $\begin{array}{l}\text { Migraine and hair } \\
\text { falls }\end{array}$ \\
\hline Mid Feb - mid Mar & Phairel & $\begin{array}{l}\text { Wendlandia glabrata DC. (Pheija), Alternanthera sessilis (L.) R.Br. ex } \\
\text { DC. (Phakchet), Plantago erosa (Yempat) }\end{array}$ & $\begin{array}{l}\text { Dermatological } \\
\text { problems }\end{array}$ \\
\hline Mid Mar - mid Apr & Lamta & $\begin{array}{l}\text { Dolichos lablab L. (Hawai-thangpak), Lysimachia parvifolia Franch } \\
\text { (Kengoi) }\end{array}$ & $\begin{array}{l}\text { Leucorrhoea or } \\
\text { white discharge }\end{array}$ \\
\hline
\end{tabular}

